Canadian

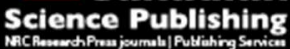

Environmental Reviews Dossiers environnement

\title{
Nitrogen cycles in terrestrial ecosystems: climate change impacts and mitigation
}

\begin{tabular}{|c|c|}
\hline Journal: & Environmental Reviews \\
\hline Manuscript ID & er-2015-0066.R2 \\
\hline Manuscript Type: & Review \\
\hline Date Submitted by the Author: & 14-Jan-2016 \\
\hline Complete List of Authors: & $\begin{array}{l}\text { Xu, Zhenzhu; Institute of Botany, Chinese Academy of Sciences, State Key } \\
\text { Laboratory of Vegetation and Environmental Change } \\
\text { Jiang, Yanling; Institute of Botany, Chinese Academy of Sciences, State } \\
\text { Key Laboratory of Vegetation and Environmental Change } \\
\text { Zhou, Guangsheng; Institute of Botany, Chinese Academy of Sciences, } \\
\text { State Key Laboratory of Vegetation and Environmental Change }\end{array}$ \\
\hline Keyword: & $\begin{array}{l}\text { Nitrogen cycle, Nitrogen deposition, Nitrogen management, Terrestrial } \\
\text { ecosystems, Climate change }\end{array}$ \\
\hline
\end{tabular}

\section{SCHOLARONE ${ }^{m}$ \\ Manuscripts}




\section{Nitrogen cycles in terrestrial ecosystems: climate change impacts and mitigation}

2

3 Zhenzhu $\mathrm{Xu}^{\mathrm{a}}$, Yanling Jiang ${ }^{\mathrm{a}}$, and Guangsheng Zhou ${ }^{\mathrm{a}, \mathrm{b}}$

$4 \quad{ }^{a}$ State Key Laboratory of Vegetation and Environmental Change, Institute of Botany, Chinese Academy of

$5 \quad$ Sciences, Beijing 100093, China

$6 \quad{ }^{\mathrm{b}}$ Chinese Academy of Meteorological Sciences, Beijing 100081, China.

7 Corresponding author:

8 E-mail address: xuzz@ibcas.ac.cn
10

11

12

\section{Abstract}

The nitrogen $(\mathrm{N})$ cycle and $\mathrm{N}$ balance have primarily been modified by anthropogenic activities and environmental changes at various scales, including biological individual, ecosystem, local landscape, continental region and global scales. These modifications have drastically affected the structures and functions of natural and agricultural ecosystems in terrestrial and aquatic areas. In this manuscript, we first present a modified view of the global $\mathrm{N}$ cycle that includes $\mathrm{N}$ transport, conversion, and exchange processes. Second, several crucial issues concerning $\mathrm{N}$ balance, including $\mathrm{N}$ deposition and excessive addition and the dynamics of $\mathrm{N}$ and other nutrients, are reviewed. Third, the effects of climate change factors including water status, warming, and elevated $\mathrm{CO}_{2}$ concentrations, on $\mathrm{N}$ balance and the $\mathrm{N}$ cycle and their interactions within and with other environmental factors are outlined. Finally, intervention strategies for improving $\mathrm{N}$ balance/cycling to address rapid continual climatic change and socio-economic development are presented and discussed. It is highlighted that the altered $\mathrm{N}$ balance and cycle between the geosphere, biosphere and atmosphere have produced the profoundly critical challenge of maintaining nitrogen levels within an appropriate range, which should be considered by relevant sectors and people, including researchers, 
managers, and policy makers from ecological, environmental, and sustainable development aspects.

Key words: Nitrogen cycle, nitrogen deposition, excessive nitrogen addition, nitrogen management, terrestrial ecosystems, climate change.

\section{Introduction}

Nitrogen $(\mathrm{N})$ is an important element in biogeochemical cycles and plays a pivotal role in regulating ecosystem structure and function (Vitousek et al. 1997; Fowler et al. 2013; Feng et al. 2015). However, great adverse impacts on the global $\mathrm{N}$ cycle have predominately resulted from anthropogenic activities, such as substantial fossil fuel combustion with rapid urbanization, excessive $\mathrm{N}$ application in intensive agricultural ecosystems with low $\mathrm{N}$ use efficiency (NUE), and enhanced $\mathrm{N}$ efflux from the rapid development of intensive livestock production systems (Galloway et al. 2008; Gruber1 and Galloway 2008; Ju et al. 2009; Paulot et al. 2013; Riha et al. 2014). Thus, this issue has become an important global concern (Sutton et al. 2012; Liu et al. 2013; Ciais et al. 2013; Fowler et al. 2013; Bechmann et al. 2014). Conversely, through a chain of chemical reactions and multi-transport processes, these emissions have resulted in the deposition of significant amounts of atmospheric $\mathrm{N}$ in terrestrial and aquatic ecosystems, which has led to ecosystem malfunction and environmental consequences, particularly with continual climatic change (Vitousek et al. 1997; Galloway et al. 2008; Gerber et al. 2010; Liu et al. 2013; Riha et al. 2014; Malik and Tauler 2015). Understanding the nitrogen cycle and its driving factors is important for evaluating the dynamics of $\mathrm{N}$ deposition and their effects on agricultural and natural ecosystems and for determining feasible and adaptable mitigation measures (Galloway et al. 2008; Liu et al. 2013; Dietze et al. 2013; Suddick et al. 2013; Rütting and Andresen 2015; Stevens et al. 2015). Here we review altered nitrogen cycle processes relative to the conventional cycle. The processes we review include the modified concepts of $\mathrm{N}$ dynamics, $\mathrm{N}$ deposition, $\mathrm{N}$ 
contamination and, particularly, the environmental impacts on $\mathrm{N}$ cycle and its feedback across major $\mathrm{N}$ conversion and exchange processes (Fig. 1). Several critical concerns regarding $\mathrm{N}$ balance and the effects of climatic change are outlined. Finally, intervention management strategies for improving $\mathrm{N}$ balance/cycling to address rapid socio-economic development, continual climate change and other environmental pressures are presented and discussed.

\section{Nitrogen deposition and dynamics in ecosystems}

\subsection{Atmospheric nitrogen deposition}

Atmospheric $\mathrm{N}$ deposition $\left(\mathrm{N}_{\mathrm{dep}}\right)$ is becoming an important component in the global $\mathrm{N}$ cycle and has led to severe issues regarding the imbalance of $\mathrm{N}$ in ecosystems (Galloway et al. 2008; Fowler et al. 2013), while anthropogenic $\mathrm{N}$ input (e.g. fertilizer and manure) is a dominant contributor to atmospheric $\mathrm{N}_{\mathrm{dep}}$ at continental and regional scales (Galloway et al. 2008; Paulot et al. 2013). Generally, anthropogenic N components are emitted into the atmosphere in two forms, $\mathrm{N}$ oxides $\left(\mathrm{NO}_{\mathrm{x}}=\mathrm{NO}+\mathrm{NO}_{2}\right)$, primarily due to fossil fuel combustion, and ammonia $\left(\mathrm{NH}_{3}\right)$ mainly from the agricultural sector; while $\mathrm{N}_{2} \mathrm{O}$ mainly are emitted from soil during denitrification (Paulot et al. 2013, Bouwman et al. 2013; Fig. 1). Based on the report by Fowler et al. (2013), the annual emissions from land in the form of $\mathrm{NO}_{\mathrm{x}}, \mathrm{NH}_{3}$, and $\mathrm{N}_{2} \mathrm{O}$ are about $35 \mathrm{Tg} \mathrm{N}, 60 \mathrm{Tg} \mathrm{N}, 13 \mathrm{Tg} \mathrm{N}$, respectively. After chemical conversion and physical transport, $\mathrm{NO}_{\mathrm{x}}$ and $\mathrm{NH}_{3}$ are removed by wet scavenging and dry deposition in the earth's ecosystems. Reportedly, the portion of reactive $\mathrm{N}\left(\mathrm{Nr}\right.$, all nitrogen forms other than $\mathrm{N}_{2}$ ) that is returned to the land and ocean accounts for $60-80 \%$ of the total $\mathrm{N}_{\mathrm{r}}$ emitted to atmosphere (Dentener and Crutzen 1994; Moffat 1998; Zhang et al. 2012; Jia et al. 2013).

Globally, the total amount of $\mathrm{Nr}$ emitted to the atmosphere increased from $15 \mathrm{Tg} \mathrm{N} \mathrm{a}^{-1}$ in 1860 to $187 \mathrm{Tg} \mathrm{N}$ $\mathrm{a}^{-1}$ in 2005, with a continued acceleration of $\mathrm{Nr}$ every year (Galloway et al. 2008). From another assessment report, the global annual mean atmospheric deposition rate has reached $c .180 \mathrm{Tg} \mathrm{N} \mathrm{a}^{-1}$, primarily in reduced 
form from anthropogenic sources (Fowler et al. 2013).

For example, $\mathrm{N}$ deposition in China, a rapidly developing nation, has quickly increased in recent decades

(Jia et al. 2013; Sheng et al. 2013). This increase likely resulted from large increases in both energy consumption and $\mathrm{N}$ fertilizer use, the two dominant human activities that affect $\mathrm{N}$ deposition (Sutton et al. 2011; Jia et al. 2013; Sheng et al. 2013). Based on data from 280 observational sites, national-scale inorganic $\mathrm{N}_{\text {dep }}$ patterns demonstrated a continual increase of $c .25 \%$ of the mean $\mathrm{N}_{\text {dep }}$ over China $\left(11.1 \mathrm{~kg} \mathrm{ha}^{-1} \mathrm{a}^{-1}\right.$ in the 1990s vs $13.9 \mathrm{~kg} \mathrm{ha}^{-1} \mathrm{a}^{-1}$ in the 2000s, Jia et al. 2013). The highest $\mathrm{N}_{\text {dep }}$ of $30 \mathrm{~kg} \mathrm{ha}^{-1} \mathrm{a}^{-1}$ occurred in southern China and decreased to western and northern China (Jia et al. 2013). However, in Northern China, a N deposit of $80 \mathrm{~kg} \mathrm{ha}^{-1} \mathrm{a}^{-1}$ was recorded in an agro-ecosystem (He et al. 2007), which significantly exceeds the critical load of $10 \mathrm{~kg} \mathrm{~N} \mathrm{ha}^{-1} \mathrm{a}^{-1}$ (He et al. 2007). Exceeding the critical load has been known to have notable effects on native vegetation (e.g., Bobbink et al. 1998; Dentener et al. 2006). As suggested, the changes in $\mathrm{N}_{\text {dep }}$ depend on human activities, such as the application of $\mathrm{N}$ fertilizer, and climatic factors such as precipitation patterns (Jia et al. 2013). For example, Jia et al. (2013) indicated that a combination of anthropogenic sources, including the application of $\mathrm{N}$ fertilizer and energy consumption, and precipitation, accounts for $79 \%$ of the spatial variations of $\mathrm{N}_{\mathrm{dep}}$.

Nitrous oxide $\left(\mathrm{N}_{2} \mathrm{O}\right)$, one of the six major greenhouse gases, has recently received great attention due to its significant greenhouse effect (Bouwman et al. 2013; Ciais et al. 2013). More $\mathrm{N}_{2} \mathrm{O}$ could be produced as an intermediate or side-product in conventional biological nutrient removal (BNR) processes consisting of the two steps-nitrification and denitrification in wastewater treatment plants (Bouwman et al. 2013). A novel treatment technology with Anaerobic Ammonium Oxidation (Anammox) pathway can substantially remove $\mathrm{N}$ due to its low energy consumption and high removal efficiency with extremely low $\mathrm{N}_{2} \mathrm{O}$ and $\mathrm{CO}_{2}$ emissions. Thus, with Anammox microorganisms, in treating ammonium-rich wastewater, ammonium can be directly oxidized to nitrogen gas with the presence of nitrite as electron acceptor thereby circumventing 
nitrification and denitrification (Meng 2012, and therein; Fig. 1).

\subsection{Nitrogen dynamics in ecosystems}

The major processes that $\mathrm{N}$ have participated in the ecosystems were depicted in Fig. 1. Briefly, atmospheric $\mathrm{N}$ is transformed by lighting process, biological $\mathrm{N}_{2}$ fixation, $\mathrm{N}$ deposition, Haber-Bosch process, and through application $\mathrm{N}$ fertilizer, finally imported into terrestrial and aquatic ecosystems. In plants, $\mathrm{N}$ converts from $\mathrm{NO}_{3}^{-1}$ into $\mathrm{NH}_{4}{ }^{+}$by nitrate reductase and nitrite reductase involvements, and continual conversions between crops, animal and people. In soil, $\mathrm{N}$ in organic matter is first mineralized to inorganic $\mathrm{N}$ forms such as $\mathrm{NH}_{4}^{+}$ and $\mathrm{NO}_{3}{ }^{-}$, in which nitrification occurs with microbial involvements; some $\mathrm{N}$ components can be fixed in soil as an immobilized form. Thereafter, available inorganic $\mathrm{N}$ is absorbed by plant roots, again entering plant tissues. Nitrogen emission pathways mainly include denitrification in soil, Anammox reaction, gaseous $\mathrm{N}$ emission processes, and fossil fuel consumption (e.g., Lam et al. 1996; Aber et al. 1998; Galloway et al. 2008; Meng 2012; Fowler et al. 2013; Chen et al. 2014b). As early as 1989, Aber et al. (1989) indicated two major pathways by which $\mathrm{N}$ enters ecosystems: pulse fertilizer addition and chronic atmospheric deposition. The amount of $\mathrm{N}$ entering an ecosystem over several years may exceed the capacity of an ecosystem for uptaking and retaining $\mathrm{N}$ in soils, plants, and microbes, resulting in nitrogen saturation, and potentially $\mathrm{N}$ leaching (Aber et al. 1989, 1998; Kopáček et al. 2013; Bechmann et al. 2014). For instance, in temperate forest ecosystems, Aber et al. $(1989,1998)$ suggested that $\mathrm{N}$ levels could be described from nitrogen-limited to nitrogen-saturated processes. As suggested, the nitrogen level dynamic phase in any ecosystem can be separated into four stages: $\mathrm{N}$ limitation, $\mathrm{N}$ balance maintenance, $\mathrm{N}$ saturation, and $\mathrm{N}$ excessive stages (Aber et al. 1989, Kopáček et al. 2013). Bechmann et al. (2014) recently redefined nitrogen balances according to $\mathrm{N}$ inputs by atmospheric deposition, fertilizer and manure addition, and fixation minus $\mathrm{N}$ outputs with yields. The relationships between the annual $\mathrm{N}$ balances for the agricultural area in the catchments and the concentrations of $\mathrm{N}$ in the streams were volatile (Bechmann et al. 2014). In addition, positive relationships 
116

117

118

119

120

121

122

123

124

125

126

127

128

129

130

131

132

between agricultural production intensity and $\mathrm{N}$ surplus were easily identified in these areas by monitoring data from the Nordic-Baltic region over 20 years (Bechmann et al. 2014). N deposition in Rocky Mountain National Park, Colorado, USA potentially resulted in a greater than $10 \%$ increase in vegetation in subalpine plant communities (McDonnell et al. 2014). A study of a semiarid grassland in north China by Wang et al. (2015) found that a modest addition of $\mathrm{N}$ may enhance both aboveground production and belowground microbial $\mathrm{N}$ transformation in soil including nitrification and mineralization. However, in some natural ecosystems, excessive $\mathrm{N}$ input may also result in soil acidification, that might offset the beneficial effects from $\mathrm{N}$ input fertilization (Wedin and Tilman 1996; Bai et al. et al. 2010). For instance, although $\mathrm{N}$ additions enhanced the total community production, plant community stability was negatively affected with the dominant native species being replaced by other secondary species (Wedin and Tilman 1996; Bai et al. et al. 2010). In addition, the belowground communities such as bacterial, fungal, and actinobacteria were also suppressed by soil acidification, indicating that abnormal $\mathrm{N}$ enrichment may decrease the linkage between aboveground and belowground components in semiarid grassland ecosystems (Bai et al. et al. 2010; Chen et al. 2015b). Soil acidification induced by $\mathrm{N}$ deposit may also limit forest ecosystem productivity and thus global-scale biodiversity (see a synthesis by Bobbink et al. 2010).

Land-use changes can alter the soil $\mathrm{N}$ status, and natural succession could enhance the $\mathrm{N}$ conservative capacities of terrestrial ecosystems (Deng et al. 2014). During vegetation growth in the central part of the Loess Plateau, China, $\mathrm{N}$ storage was observed to rapidly increase in the $0-60 \mathrm{~cm}$ soil layer before reaching a stable value after the emergence of the shrub community stage (50-60 years). This process resulted in the dramatic accumulation of long-term soil $\mathrm{N}$ storage (c. 150 years) in secondary forests (Deng et al. 2014). Although biodiversity in an ecosystem may be closely linked with $\mathrm{N}$ dynamics, it remains an area of controversy (Vitousek et al. 1997; Cardinale 2011; McDonnell et al. 2014). Bracken and Stachowicz (2006) observed that an increase in seaweed diversity may promote nitrogen uptake due to the complementary use 
of nitrate and ammonium. Recently, a study provided evidence that increased species richness could provoke

$\mathrm{N}$ accumulation in biological organisms in freshwater ecosystems (Cardinale 2011). Whether a high level of biodiversity can enhance the nitrate and ammonium uptake and storage and the feedback remains debatable, despite actual findings that the rapid accumulation of nitrate in terrestrial ecosystem has become a cause for global concern and potentially results in adverse feedback to ecosystem structure and function (Vitousek et al. 1997; Cardinale 2011). Additionally, NO emissions from a variety of different plant species have been observed, but further investigation is required (Chen et al. 2015c).

\subsection{Nitrogen dynamics with other nutritious components}

$\mathrm{N}$, carbon (C) and sulphur (S) cycles may be associated with the biogeochemical cycle from a single ecosystem up to the global scale. For example, with $\mathrm{N}$ saturation, a transition from $\mathrm{N}$ to $\mathrm{C}$ limitation may appear (Kopáček et al. 2013)—available $\mathrm{N}$ exceeds plant and microbial demand in a vegetation ecosystem, consequently an increase in $\mathrm{N}$ would not increase, and may even decrease, plant and microbial biomass under saturating N conditions (Aber et al. 1998; Kardol et al. 2012; Wei et al. 2013). At N-saturated ecosystems, a sharp decline in C:N might appear, such as a decrease of $\sim 20 \%$ in tree leaves in a temperate forest ecosystems (Aber et al. 1998), and a decrease of $\sim 12 \%$ in a sagebrush-crested wheatgrass soil (Chen and Stark 2000). However, in coniferous forests, C:N ratio remained high in N-saturated soil (Gundersen et al. 1998), this trends needs to be better understood (Delgado-Baquerizo et al. 2013; Zhang et al. 2014). Moreover, in N-rich systems, lower amounts of bio-available dissolved organic C (DOC) may result in a C limitation for the microbial community. In these systems, the following three mechanisms have been hypothesized (Kopáček et al. 2013): (1) increased abundance of $\mathrm{N}$ for plant uptake, resulting in lower C allocation to plant roots; (2) chemical suppression of DOC solubility by soil acidification; and (3) enhanced mineralization of DOC due to an increase in the number of electron acceptors for $\mathrm{SO}_{4}{ }^{2-}$ and $\mathrm{NO}_{3}{ }^{-1}$ under anoxic soil conditions (Kopáček et al. 2013). However, the dynamics of available P may not be closely 
162

163

164

165

166

167

168

169

170

171

172

associated with $\mathrm{C}$ and $\mathrm{N}$ (Smeck 1985). The availability of $\mathrm{C}$ and $\mathrm{N}$ is closely linked to the microbial mineralization primarily derived from organic matter, whereas the available $\mathrm{P}$ for plants and microorganisms could be mainly derived from mechanical rock weathering (Smeck 1985). However, P and iron limitations may play a predominant role in stabilizing the $\mathrm{N}$ inventory of marine ecosystem through the interactions of $\mathrm{N}_{2}$ fixation and denitrification (Dietze et al. 2013), and current soil $\mathrm{C}, \mathrm{N}$ and $\mathrm{P}$ status is linked to the long-term P weathering using a new model, N14CP (Davies et al. 2016). The balance between the major nutrients may be altered with environmental change, particularly under climatic change condition (Delgado-Baquerizo et al. 2013; Yuan and Chen 2015). For example, Delgado-Baquerizo et al. (2013) examined the effects of dryland aridity, which are expected to continue due to the great $\mathrm{N}$ deposit, and implied that a predicted increase in aridity may increase the available inorganic $\mathrm{P}$ concentration, mainly due to rock weathering, relative to $\mathrm{C}$ and $\mathrm{N}$, possibly leading to an decoupling of the $\mathrm{C}, \mathrm{N}$ and $\mathrm{P}$ cycles in drylands (Delgado-Baquerizo et al. 2013). Recently, Yuan and Chen (2015) reported that terrestrial plant N:P can decrease with elevated $\mathrm{CO}_{2}$ and increased precipitation, but increases with climate warming, reduced precipitation, and $\mathrm{N}$ addition, indicating that a decoupling of $\mathrm{N}$ and $\mathrm{P}$ in terrestrial ecosystem may occur under global changes. Consequently, the biogeochemical processes that control key ecosystem functions and services, such as plant growth, community productivity, soil respiration, litter decomposition, and subsequent soil carbon storage, were changed, depending on the site, local, and regional to global scales (Finzi et al. 2011; Delgado-Baquerizo et al. 2013; Yuan and Chen 2015). A recent report from field-fertilizing experiments on typical temperate grasslands in China indicated that the addition of $\mathrm{N}$ with $\mathrm{P}$ and $\mathrm{K}$ treatments significantly enhanced $\mathrm{N}_{2} \mathrm{O}$ emissions relative to $\mathrm{N}$ application alone (Zhang et al. 2014). This result implies that the other essential elements involved in soil microbial metabolism may also promote $\mathrm{N}$ turnover processes and accelerate soil $\mathrm{N}$ release. Furthermore, the nitrate production and mobility responses of an ecosystem to environmental change could be regulated by iron, which is involved in reduction 
185

processes by serving as a catalyst when nitrate is reduced to nitrite (Aber et al. 1998; Davidson et al. 2003).

However, this mechanism remains controversial ( $\mathrm{Li}$ et al. 2012). In addition, land-use changes significantly affect $\mathrm{N}$ cycling features and stoichiometry (Davidson et al. 2007; Townsend et al. 2007). For example, conservative $\mathrm{N}$-cycling properties appeared in young successional forests that were grown after agricultural abandonment. However, as secondary succession progresses, N-cycling properties may recover and a conservative P cycle may occur, which would lead to a shift in the N:P ratio (Davidson et al. 2007). This result indicates that the dynamic features and balance of $\mathrm{N}$ relative to other nutrition elements might be easily altered with land-use changes involving anthropogenic disturbance across the timescales.

\section{Effects of $\mathbf{N}$ deposition and consequences of excessive $\mathbf{N}$ addition}

Large increases in $\mathrm{N}_{\text {dep }}$ exerted dramatic beneficial and deleterious impacts on terrestrial ecosystems (Aber et al. 1998; Galloway et al. 2008; Sutton et al. 2012; Fowler et al. 2013; Wårlind et al. 2014). The advantageous aspect appears often in ecosystems that are frequently limited by $\mathrm{N}$ availability (Aber et al. 1998; Fowler et al. 2013; Davies et al. 2016). These aspects include increases in soil $\mathrm{N}$ availability; plant $\mathrm{N}$ uptake; plant foliar N concentrations in natural ecosystems, such as grasslands and forests (Rustad et al. 2001; Hyvönen et al. 2007); and crop $\mathrm{N}$ uptake and grain protein contents in agricultural ecosystems (Fowler et al. 2013; Liu et al. 2013). These processes positively alter soil nutrition status (Goulding et al. 1998), stimulate the development of the vegetation canopy (Reay et al. 2008; Fang et al. 2014), and result in an enhanced carbon sink (Wårlind et al. 2014; Fang et al. 2014). On the other hand, currently dramatic N deposition and excessive $\mathrm{N}$ fertilizer application can produce deleterious impacts, including severe soil acidification (Bowman et al. 2008; Yang et al. 2012; Fowler et al. 2013), loss of indigenous species and biodiversity (Goulding et al. 1998; Clark and Tilman 2008; Jia et al. 2013; Zhang et al. 2014) including the loss of soil microbial diversity (Zeng et al. 2016), un-linkage between aboveground biomass and belowground microbial 
activities (mainly due to acidification) (Liu et al. 2014), decoupling of the C-N-P stoichiometric balance in surface soils over geographical regions (Yang et al. 2014; Yuan and Chen 2015), exacerbation of greenhouse gas imbalance (Galloway et al. 2008), and extra eutrophication and excessive N saturation in some ecosystems (Goulding et al. 1998; Bechmann et al. 2014). For instance, a major concern has emerged regarding soil acidification in intensive agricultural cropland systems in China, mainly due to the overuse of fertilizer application for pursuing high agricultural production to meet increasing demands for food (Guo et al. 2010; Yang et al. 2012). Soil acidification induced by N deposition also occurred in coniferous and mixed coniferous and broadleaved forests (Yang et al. 2015). In some intensive agricultural ecosystems, such as in wheat-maize cropping systems in a major grain production zone, excessive nitrogen application could decrease grain yield and could easily lead to nitrogen loss, which could result in environmental contamination (Wang et al. 2011; Xu et al. 2013; Lu et al. 2014). However, from a recent report by Chapman et al. (2015), the deciduous forest understory plant community of N-rich forested ecosystems can remain stable with excessively increasing $\mathrm{N}$ availability. Thus, there are arguments on $\mathrm{N}$ deposition issue.

Environmental changes and management practices may affect the $\mathrm{N}$ dynamics of ecosystems. For example, concentrated summer rainfall can increase ammonia volatilization by $19 \%$ - 24\% (Ju et al. 2009). In wheat/maize systems in calcareous soils in the major grain production zone of China, $\mathrm{N}$ loss primarily occurred through nitrate leaching pathways (Ju et al. 2009). In these areas, a higher $\mathrm{N}$ loss rate was often observed in rice/wheat systems than in wheat/maize systems, and the ratios of ammonia volatilization loss to applied nitrogen were 16.6-18.4\% when different amounts of nitrogen were applied in a rice field (Chen et al. 2015a). These results indicated that different forms of $\mathrm{N}$ loss and different rates of $\mathrm{N}$ loss could occur for different vegetation types ( $\mathrm{Ju}$ et al. 2009; Chen et al. 2014a). Based on a recent report from Northern Lithuania (Masilionytè et al. 2014), the lowest soil mineral nitrogen concentration (0-40 cm soil layer) was observed, and the risk of leaching into deeper layers was lower in organic cropping systems with catch crops 
231 (e.g. winter wheat + catch crops), which suggested that the agro-ecosystems using organic cropping systems

232 with catch crops resulted in lower diffuse nitrogen pollution in some areas (Masilionyte et al. 2014).

233 Increased mineralization always enhances $\mathrm{N}$ uptake by crops and may increase the risk of $\mathrm{N}$ loss (Chen et al.

234 2014a). Plant residues can change the fate of inorganic $\mathrm{N}$ via three mechanisms: mineralization,

235 immobilization-mineralization, and immobilization. For these mechanisms, plant residue characteristics and

236 field soil properties may play a critical role. Recent reports by Chen et al. (2014) have indicated that $\mathrm{Nr}$

237 losses could be limited in integrated soil-crop systems in China based on the local environmental conditions,

238 appropriate varieties, regulated planting dates and densities, and improved nutrient management, which

239 could increase productivity while reducing the environmental costs of intensive agriculture (Chen et al.

240 2011a, 2014; Masilionyte et al. 2014). Through analyzing a set of results from simulations with two models,

241 Durand et al. (2015) indicated that the reducing $\mathrm{N}$ input and increasing grassland would efficiently mitigate

242 nitrogen pollution in farming catchments.

243

244

245

246

247

\section{Effects of climate change on $\mathrm{N}$ balance/cycling}

\subsection{Water status effects}

Climatic controls on biogeochemical cycles, including $\mathrm{N}$ balance, are more sensitive in arid and semi-arid areas because the biological activity in these areas is primarily driven by water deficit (Delgado-Baquerizo et al. 2013). In an acidic coniferous forest in Norway, the water deficit stress can reduce gross $\mathrm{N}$ turnover rates, including ammonification and nitrification processes (Chen et al. 2011b). In contrast, greater precipitation could enhance $\mathrm{N}_{2} \mathrm{O}$ emissions. For example, the acceleration of the $\mathrm{N}$ cycling process under increased precipitation may lead to an increase in the release of $\mathrm{N}_{2} \mathrm{O}$ in grazed grasslands in New Zealand (de Klein et al. 2015). Larsen et al. (2011) indicated that water deficit could weaken belowground gross $\mathrm{N}$ mineralization and decrease the mass of soil fauna $\mathrm{N}$ in Danish heathland ecosystems. The same scenario, i.e., limitations in 
the $\mathrm{N}$ mineralization rate and nitrate production under water deficit conditions, was also found for farmlands (Wang et al. 2008). Nevertheless, whether nitrification is more sensitive to desiccation than ammonification and to what extent $\mathrm{N}$ turnover occurs depends on different soil horizons and the type of vegetation (Chen et al. 2011b; Larsen et al. 2011). However, an increased efflux of inorganic nitrogen was observed during a drought period in an annual grassland in California (Jackson et al. 1988). Drought can result in the allocation of more plant $\mathrm{N}$ in sink organs, such as roots (Xu and $\mathrm{Yu}$ 2005; Xu et al. 2007), and limit the absorption of soil $\mathrm{N}$ by plants (Yuan et al. 2006). Thus, relatively stable or high $\mathrm{N}$ levels remain in the soil during drought.

Water stress can decrease nitrate reductase (NR) activity and other positive $\mathrm{N}$ anabolic processes in plants (Neeru et al. 1998; Xu and Zhou 2006a). Severe drought can decrease the protein contents of plant tissues and the ratio between protein $\mathrm{N}$ and total $\mathrm{N}$ (Xu and Zhou 2006ab), and waterlogging can decrease the $\mathrm{N}$ content and the amount of $\mathrm{N}$ accumulated in the plant roots in winter wheat by $12 \%-39 \%$. Furthermore, waterlogging can increase the C:N ratio by $80 \%$, which would weaken synthetic $\mathrm{N}$ metabolism in the plant roots (Zhou et al. 2001; Xu and Zhou 2004, 2006b). In addition, the water status may also affect $\mathrm{N}_{2}$ fixation processes in relative ecosystems. For instance, severe drought could constrain the $\mathrm{N}_{2}$ fixation rate in common bean, in which droughts affect the transportation of ureides from the nodules and the accumulation of $\mathrm{N}$ in the stems and leaves (Coleto et al. 2014). Thus, water status may play an important role in regulating the $\mathrm{N}_{2}$ fixation bioprocess (Vadez et al. 2000; Coleto et al. 2014).

\subsection{Temperature effects}

High temperatures affect belowground and aboveground N metabolic processes. Rustad et al. (2001) analyzed data from warming experiments in ecosystems at 32 research sites that represented four broadly defined biomes, including high and low tundra, grassland, and forest; and the result showed that temperature increases of $0.3-6.0^{\circ} \mathrm{C}$ significantly increased the net $\mathrm{N}$ mineralization rates in the soil by $46 \%$. However, Gestel et al. (2011) reported reductions of 16-18\% after 3 years of warming in the dissolved forms of soil N, 
$277 \mathrm{NO}_{3}{ }^{-}-\mathrm{N}$ and $\mathrm{NH}_{4}{ }^{+}-\mathrm{N}$. Nitrate and ammonia are usually recognized as the two dominant forms of soil available N. Xia et al. (2009) indicated that a temperature increase of $1.8^{\circ} \mathrm{C}$ in the surface soil did not change the soil available $\mathrm{N}$ content according to the sum of the $\mathrm{NH}_{4}{ }^{+}$and $\mathrm{NO}_{3}{ }^{-}$concentrations. However, in a Danish heathland, warming increased the $\mathrm{N}$ turnover based on the high rates of microbial $\mathrm{NH}_{4}{ }^{+}$consumption, gross mineralization, potential nitrification, denitrification and $\mathrm{N}_{2} \mathrm{O}$ emissions (Larsen et al. 2011). In addition, the decomposition in the soil was marginally accelerated by warming in a tidal marsh in Massachusetts, USA (Charles and Dukes 2009). Furthermore, $\mathrm{N}_{2}$ fixation was promoted by warming in a subarctic moist heath in Northern Sweden (Sorensen and Michelsen 2011). $\mathrm{N}_{2}$ fixation and $\mathrm{N}_{2} \mathrm{O}$ emissions were enhanced as the temperature increased in a New Zealand grassland (de Klein et al. 2015). Within plants, heat stress limited the accumulation of leaf $\mathrm{N}$ and decreased nitrogen availability (Wollenweber et al. 2003). Decreases in $\mathrm{N}$ anabolic processes, such as decreases in NR and glutamine synthetase (GS) activities, and increasing catabolism, such as an increase in endopeptidase activity, were found at high temperature above optimum

(Xu and Zhou 2006a). Modifications in molecular composition have been highlighted with warming based on higher levels of the expression of some genes and the enhanced synthesis of some heat-stress proteins (see a review by Penuelas et al. 2013). Furthermore, when the temperature is high, a decrease in the proportion of soluble protein to total leaf $\mathrm{N}$ may suppress the Rubisco activity and produce a negative effect on the photosynthetic capacity (Sicher and Bunce 1997; Xu and Zhou 2006a; Xu et al. 2013b). Thus, extremely aboveground.

\subsection{Elevated $\mathrm{CO}_{2}$ concentration effects}

Elevated atmospheric $\mathrm{CO}_{2}$ concentrations (elevated $\mathrm{CO}_{2}$ ) may substantially affect terrestrial and aquatic ecosystems regarding their ecological processes, including ecosystem structure, plant physiological activity 
and species successions (e.g., O’Neill 1995; Gutiérrez et al. 2013; Xu et al. 2014; Feng et al. 2015; Xu et al. 2015). Long-term elevated $\mathrm{CO}_{2}$ can decrease the $\mathrm{N}$ contents of plant tissues, which are referred to as the $\mathrm{N}$ dilution effectiveness and/or progressive $\mathrm{N}$ limitation to plants (PNL) - this means that increased productivity from enhanced catalytic activity of Rubisco by elevated $\mathrm{CO}_{2}$ does not necessarily match with enhanced N in plant tissue that results in N dilution (Farage et al. 1998; Davey et al. 1999; Gutiérrez et al. 2013). Thus, elevated $\mathrm{CO}_{2}$ levels directly inhibit plant nitrogen metabolism and relevant physiological processes, particularly during long-term $\mathrm{CO}_{2}$ enrichment (Conroy 1992; Luo et al. 2004; Larsen et al. 2011; Gutiérrez et al. 2013; Bloom et al. 2014). As suggested by Luo et al. (2004), in the presence of high $\mathrm{CO}_{2}$ levels, the available $\mathrm{N}$ in soils, plants, and ecosystems becomes increasingly limiting as the net primary productivity (NPP) and soil organic matter (SOM) content continually increase. For instance, Gutiérrez et al. (2013) reported that elevated $\mathrm{CO}_{2}$ could decrease the leaf $\mathrm{N}$ and Rubisco contents by $14 \%$ and $21 \%$, respectively, in Triticum aestivum plants. This $\mathrm{N}$ dilution could lead to photosynthetic acclimation or the down-regulation of the photosynthetic capacity (Adachi et al. 2014), and reduce the protein grain concentrations in crops. For instance, there were decreases of 10-15\% in the grain protein concentrations in wheat, barley and rice (Taub et al. 2008), and an average decrease of approximately $8 \%$ in wheat grain, rice grain, potato tuber and barley grain (Bloom et al. 2014), thereby decreasing product quality. On the other hand, when plant $\mathrm{N}$ contents are low, the plants may increase their NUE to counteract the N deficit, e.g., increasing their photosynthetic N use efficiency (PNUE) in green photosynthetic organs (Davey et al. 1999). A recent report by Feng et al. (2015) indicated that a significant positive relationship occurred between the stimulation of plant productivity and $\mathrm{N}$ acquisition when $\mathrm{CO}_{2}$ concentrations were elevated for a long period in a Free-Air $\mathrm{CO}_{2}$ Enrichment (FACE) experiment. In addition, this study indicated that an increase in $\mathrm{N}$ limitations relative to enhanced ecosystem productivity could result in a decrease in plant $\mathrm{N}$ acquisition (Feng et al. 2015), which implies that an adaptive response of $\mathrm{N}$ balance occurs in ecosystems. More $\mathrm{N}$ could 
323 be allocated to belowground tissues under high $\mathrm{CO}_{2}$ conditions (e.g., Cotrufo et al. 1998). Elevated $\mathrm{CO}_{2}$

324

325

326

327

328

329

330

331

332

333 concentrations result in the transfer of more $\mathrm{N}$ into the roots than through the photosynthetic apparatus of green tissues to optimize energy costs and increase the NUE by regulating nitrogen transport and reallocation (Cotrufo et al. 1998; Luo et al. 2006; Yuan et al. 2006; Xu et al. 2007). $\mathrm{C}_{4}$ plants were not affected by elevated $\mathrm{CO}_{2}$ under ample water conditions (e.g., Leakey et al. 2006; Xu et al. 2014). Thus, PNL may not appear for the $\mathrm{C}_{4}$ plants. For instance, Bloom et al. (2012) reported that nitrate assimilation into proteins in plant tissues was inhibited by elevated $\mathrm{CO}_{2}$ in $\mathrm{C}_{3}$ species rather than $\mathrm{C}_{4}$ species. In this case, a marked suppression in leaf $\mathrm{NO}_{3}{ }^{-}$assimilation in field-grown wheat was observed under high $\left[\mathrm{CO}_{2}\right](\mathrm{Bloom}$ et al. 2012). In general, PNL in $\mathrm{C}_{3}$ plants may be greater than in $\mathrm{C}_{4}$ species, highlighting the species-specific and plant functional groups-specific responses of $\mathrm{N}$ conversions to $\mathrm{CO}_{2}$ enrichment (Xu et al. 2015).

Soil nitrogen dynamics were also affected by $\mathrm{CO}_{2}$ enrichment (O’Neill 1995). However, no general response of gross mineralization or gross nitrification to elevated $\mathrm{CO}_{2}$ was found, which depends on ecosystems and experimental methods (Rütting and Andresen 2015). For example, in a grazed grassland, elevated $\mathrm{CO}_{2}$ can accelerate $\mathrm{N}$ cycling, including increased $\mathrm{N}_{2} \mathrm{O}$ emissions, because $\mathrm{NPP}$, legume growth and biological nitrogen fixation (BNF) likely increase the amount of urine $\mathrm{N}$ deposition due to strengthened grazing (de Klein et al. 2015). $\mathrm{N}$ mineralization would be stimulated by elevated $\mathrm{CO}_{2}$ in $\mathrm{N}$ limited ecosystems, but may decrease in $\mathrm{N}_{2}$ fixing communities due to the increased $\mathrm{N}$ supply via BNF (Richter et al. 2003; Rütting and Andresen 2015). In $\mathrm{P}$ limited ecosystems, no $\mathrm{N}$ mineralization response to elevated $\mathrm{CO}_{2}$ was observed because no association occurred between P mineralization and SOM decomposition (McGill and Cole 1981; Rütting and Andresen 2015).

Recently, van Groenigen (2014) reported that the stimulation of plant growth and carbon inputs into the soil from elevated $\mathrm{CO}_{2}$ is expected to allow the microbial response to counteract the response by resulting in faster decomposition in the soil, which is closely associated with soil N availability (Cheng et al. 2012; 
Carrillo et al. 2014; Hodge and Storer 2015). Under elevated $\mathrm{CO}_{2}$ concentrations, high $\mathrm{N}$ concentrations and

347

348

349

350

351

352

353

high $\mathrm{C}$ concentrations in root tissues may increase $\mathrm{C}$ efficiency, which indicates that elevated $\mathrm{CO}_{2}$ may shift the stoichiometric balance and that $\mathrm{N}$ availability may become more important for regulating $\mathrm{C}$ efficiency at elevated $\mathrm{CO}_{2}$ than at ambient $\mathrm{CO}_{2}$ (Carrillo et al. 2014). In addition, a world with both high $\mathrm{CO}_{2}$ and high $\mathrm{N}$ could result in greater carbon storage by soil microorganisms (Carrillo et al. 2014). In the soil, mycorrhizae, $\mathrm{N}$-fixing bacteria and actinomycetes, microbiota, plant pathogens, and soil fauna could be altered under elevated $\mathrm{CO}_{2}$ conditions (O’Neill 1995; Hu et al. 2001; Zhang et al. 2011). The diluted nitrogen concentrations in the plant litter could change the decomposition rates and expose an indirect effect on decomposer communities and their metabolic functions (O'Neill 1995; Hu et al. 2001). Hu et al. (2001) observed the effects of suppressed microbial decomposition and enhanced plant $\mathrm{N}$ uptake in an annual grassland under a long-term elevated $\mathrm{CO}_{2}$ condition. Increases in soil microbial biomass $\mathrm{C}: \mathrm{N}$ ratio and ${ }^{15} \mathrm{~N}$ content in plants were also found (Hu et al. 2001). In a soil microbial community in a grassland ecosystem, several $\mathrm{N}$ cycling genes, such as nifH and $n i r S$, were significantly promoted in response to elevated $\mathrm{CO}_{2}(\mathrm{Xu}$ et al. 2013a). Under elevated $\mathrm{CO}_{2}$, the ratio of ammonium oxidation to immobilization may decrease, which results in a tighter $\mathrm{N}$ cycle at a stable ecosystem $\mathrm{N}$ level (Rütting and Andresen 2015). Thus, under high $\mathrm{CO}_{2}$ and with future climate change, nitrogen may be reallocated between aboveground and belowground parts, which would profoundly affect bioprocesses throughout the ecosystem at the regional or global scales (Cotrufo et al. 1998; Gruber1 and Galloway 2008; Xu et al. 2013b).

One hypothesis suggests that legume species may benefit more from $\mathrm{CO}_{2}$ enrichment because they possess root nodules with high $\mathrm{N}$-fixing capacities and potentially encounter $\mathrm{N}$ dilution effects (Newton et al. 2006; Rogers et al. 2009). However, in some legume species, N-fixing activities, such as symbiotic nitrogenase activity, were not enhanced by elevated $\mathrm{CO}_{2}$ (Zhang et al. 2011). For some legumes species, $\mathrm{N}$ nutrient limitation also did not occur in response to elevated $\mathrm{CO}_{2}$, mainly because of improved availability of $\mathrm{C}, \mathrm{N}$, 
and water under elevated $\mathrm{CO}_{2}$ (Cotrufo et al. 1998; Rogers et al. 2009). The growth of legume species does not outweigh the effects of growing plants without $\mathrm{N}$-fixing bacteria under high $\mathrm{CO}_{2}$ concentrations (Campbell et al. 2000; Zhang et al. 2011; Xu et al. 2014; Yan et al. 2014), which indicates that the deficits of other nutritious elements, such as a $\mathrm{P}$, may limit the activity of $\mathrm{N}$-fixing bacteria and their regulatory response to $\mathrm{CO}_{2}$ enrichment (Rogers et al. 2009; Yoneyama et al. 2012; Rütting and Andresen 2015). The key responses of $\mathrm{N}$ processes in aboveground and belowground parts in vegetation ecosystems to climate change, such as elevated $\mathrm{CO}_{2}$, are summarized in Fig. 2.

\subsection{Multi-factor effects}

Effects on $\mathrm{N}$ cycle processes in terrestrial ecosystems may not only derive from a single climate change variable, but multiple factors may play a complex role in the $\mathrm{N}$ cycle; the combined effects might reflect a changing environmental world. For example, decomposition was marginally accelerated by warming and was enhanced with increasing precipitation in a tidal marsh in Massachusetts, USA (Charles and Dukes 2009). However, the modest warming and altered precipitation did not significantly change the ammonium concentration in a marsh ecosystem (Charles and Dukes 2009) and in arid grassland (Liu et al. 2015). Although warming or increased precipitation did not change the microbial community structure, microbes-mediated soil C losses would increase under future climate change (Zhang et al. 2013). However, a combination of heat and drought would inhibit plant $\mathrm{N}$ fixation, leading to a higher $\mathrm{C}: \mathrm{N}$ ratio in a savanna ecosystem in southern Africa (Dintwe et al. 2015). In plants, warming can exacerbate deleterious effects of drought stress on nitrogen metabolism, including decreasing the NR and GS activities and increasing the proteinase activities, which would reduce nitrogen anabolism and enhance protein catabolism (Xu and Zhou 2006a). In addition, the nitrogen absorption capacity of the plant could be weakened under the combination of drought and heat (Wollenweber et al. 2003; Xu and Zhou 2006a; Xu et al. 2007; Khan et al. 2014). As recently reported, the down-regulation of photosynthesis in rice plants grown under $\mathrm{CO}_{2}$ enrichment in 
fields may be accelerated with soil warming (Adachi et al. 2014), potentially due to increasing $\mathrm{N}$ dilution at elevated $\mathrm{CO}_{2}$ with warming. Elevated $\mathrm{CO}_{2}$ could decrease plant leaf $\mathrm{N}$ content under well-watered conditions and remains nearly stable under water deficit conditions (Xu and Zhou 2004; Xu et al. 2007), which indicates that watering regimes could modify changes in $\mathrm{N}$ levels and $\mathrm{N}$ allocation due to $\mathrm{CO}_{2}$ enrichment. Additionally, under high $\mathrm{CO}_{2}$ concentrations, nitrogen deposition may have a beneficial effect on vegetation productivity when $\mathrm{N}$ is not saturated. For instance, a recent report highlighted this enhancement in Japanese forest vegetation growth that served as a carbon sink based on the long-term observation of data across a large regional range, which corresponded with both elevated $\mathrm{CO}_{2}$ and substantial $\mathrm{N}_{\text {dep }}$ (Fang et al. 2014).

However, under low soil nutrition, $\mathrm{CO}_{2}$ enrichment may not maintain enhanced plant growth and community productivity, particularly in the long-term $\mathrm{CO}_{2}$ fumigation field, due to the dilution of key nutrients, such as N and P (Conroy 1992; Xu et al. 2013b; Reich et al. 2014). For instance, simultaneous limitations by water and nitrogen eliminated the stimulated response to elevated $\mathrm{CO}_{2}$ in a perennial grassland (Reich et al. 2014). In a subtropical forest, a decrease in the $\mathrm{N}: \mathrm{P}$ ratio due to elevated $\mathrm{CO}_{2}$ was closely linked to an increase in $\mathrm{P}$ concentration, which indicated that $\mathrm{P}$ limitation could be alleviated in the subtropical ecosystems under elevated $\mathrm{CO}_{2}$ (Liu et al. 2013), and highlighted the interactive effects of $\mathrm{CO}_{2}$ enrichment with the other essential elements in the ecosystems (Yuan and Chen 2015).

$$
\text { Moreover, as considered under the context of the multifactor-driven effects of climate, elevated } \mathrm{CO}_{2} \text { may }
$$
only have minor effects on belowground bioprocesses as warming increases and drought reduces soil $\mathrm{N}$ turnover in ecosystems (Larsen et al. 2011). Long-term multifactorial climate change could also affect mesofaunal activities related to soil $\mathrm{N}$ cycling. For example, in a dry grassland ecosystem in North Zealand, Denmark, the soil biomasses and $\mathrm{N}$ contents from mesofauna, such as oribatid and mesostigmatic mites, could increase at elevated $\mathrm{CO}_{2}$. However, this process may be inhibited when the ecosystems were subjected 
to acute heat and drought (Vestergård et al. 2015), which suggests that the soil mesofauna may be involved in the soil $\mathrm{N}$ cycling processes. Antagonistic effects may appear due to the effects of warming and drought on biological processes related to aboveground and belowground $\mathrm{N}$ metabolisms. Together, these effects may reduce $\mathrm{N}$ turnover with climate change and subsequently weaken the potential regulatory response of plant growth and productivity to elevated $\mathrm{CO}_{2}$ (Larsen et al. 2011; Penuelas et al. 2013; Xu et al. 2014) (Fig. 2). Additionally, wildfires induced by heat and drought—-the fire activities will be further exaggerated with global warming (Oris et al. 2014), may weaken $\mathrm{N}$ cycling rates such as $\mathrm{N}$ mineralization, mainly due to limitation to vegetation productivity in natural ecosystems such as forests and grasslands (Scholze et al. 2006; Reich et al. 2001; LeDuc et al. 2013; Oris et al. 2014; Pellegrini et al. 2015). Furthermore, climate change with human infrastructure, landscape, and the hydrologic residence might together control $\mathrm{N}$ denitrification based on a report in the aquatic ecosystems of the United States in USA (Baron et al. 2013). Nevertheless, unclear mechanisms regarding how global climatic change with terrestrial ecosystems control $\mathrm{N}$ availability and turnover, such as $\mathrm{N}$ fixation and organic matter decomposition, remain major challenges when assessing the N cycle with Earth system models (Thomas et al. 2015).

Using the climate model ARPEGE, Salmon-Monviola et al. (2013) reported that future climate change and elevated $\mathrm{CO}_{2}$ could influence $\mathrm{N}$ cycling through significantly increasing $\mathrm{N}$ mineralization. Bernal et al. (2012) conducted both empirical data analyses and modelling on the forest $\mathrm{N}$ cycle in northeastern United States. Their results showed that climate change alone could not explain the occurrence of a dramatic nitrate decline over past 46 years, but about 50-60\% of the $\mathrm{N}$ export could be explained by the long-lasting effect of the early forest cutting. Thus, climate change in combination with human activities may exert a complex effect on the forest nitrogen cycle (Bernal et al. 2012; Ciais et al. 2013). A recent report indicated that elevated $\mathrm{O}_{3}$ could result in greater microbial biomass $\mathrm{N}$ and stabilize the soil $\mathrm{N}$ level, which suggests that a marked interaction between the pollutants may exist (Bassin et al. 2015). Additionally, anthropogenic $\mathrm{NO}_{\mathrm{x}}$ emission 
438 is closely associated with other climatic change factors including $\mathrm{O}_{3}$ formation, a decrease in $\mathrm{CH}_{4}$, and the

439 formation of nitrate aerosols in the atmosphere, that collectively imposes a complementary feedback on

440 climate warming (Ciais et al. 2013), that warrants further investigation.

$441 \quad 4.5$. Nitrogen-carbon cycle

442 Nitrogen-carbon cycles might interact significantly at regional and global scales (Ciais et al. 2013; Huang et

al. 2016). The results of a study by Zaehle (2013) using a terrestrial biosphere model, showed that

444

445

446

447 anthropogenic nitrogen from 1860 have contributed $1.3 \mathrm{Pg} \mathrm{N}$ to the terrestrial biosphere, simultaneously increasing the carbon sequestration by $11.2 \mathrm{Pg}$ C. On the other hand, an increase in vegetation may enhance the $\mathrm{N}$ fixation in ecosystems. For example, a synthesis of published data by Elbert et al. (2012), estimated that global cryptogamic ecosystems may take up around $49 \mathrm{Tg} \mathrm{N}$ and $3.9 \mathrm{Pg}$ carbon globally per year, indicating that $\mathrm{N}$ fixation by cryptogamic covers might be another crucial factor for carbon sequestration by plants, possibly playing an important role in combating with global warming. According to a recent report by Stevens et al. (2015), anthropogenic N deposition led to pronounced great carbon sequestration by herbaceous ecosystems worldwide. These results indicated that the interaction of $\mathrm{N}$ and $\mathrm{C}$ cycle may present a negative feedback to climatic change. However, at the same time, $\mathrm{N}$ deposition-enhanced vegetation ecosystem may also provoke nitrogen losses, consequently increasing the greenhouse gas $\mathrm{N}_{2} \mathrm{O}$ in the atmosphere, partly compensating for the carbon sink-enlarged climate benefit (Zaehle 2013). In addition, in a mature tropical forest of southern China, soil carbon emission can be exacerbated based on the results of a field $\mathrm{N}$ addition experiment possibly because of a reduction in root biomass and a suppression in microbial community under N-enriched conditions (Mo et al. 2008). However, the mechanism underlying influence of $\mathrm{N}$ inputs on soil C cycle remained unclear in different types of ecosystems (Ciais et al. 2013; Du et al. 2014; Sun et al. 2014; Noormets et al. 2015). As suggested by Zaehle et al. (2015), these results caution that the full potential consequences of widespread terrestrial $\mathrm{N}$ limitation may be overlooked using the current coupled 
461 carbon cycle-climate models and earth system model ensemble. Nevertheless, given the expected continued

462 increases in $\mathrm{CO}_{2}$ levels and anthropogenic $\mathrm{Nr}$ formation in the future, current observations and modelling

463 results together show that low nitrogen availability will repress carbon sinks on land in this century (Ciais et

464 al. 2013; Zaehle et al. 2015; Huang et al. 2016). Thus, the interaction of N-C cycle and its impact and

465 feedback on climate change is complex, still remains poorly understood.

\section{Intervention strategies to improve $\mathrm{N}$ balance/cycling}

468

469

470

471

472

473

474

475

476

477

478

479

480

481

482

483

Abnormalities in the response and feedback of the nitrogen cycle have become an important environmental concern globally because $\mathrm{Nr}$ emissions could increase with adverse climate change and rapid socio-economic development (Galloway et al. 2008; Sutton et al. 2012; Liu et al. 2013; Suddick et al. 2013). More importantly, however, mitigation of excess $\mathrm{Nr}$ could both repress $\mathrm{N}_{2} \mathrm{O}$ emissions and helpfully alleviate $\mathrm{CO}_{2}$, $\mathrm{CH}_{4}$, ozone effects in complex ways (Pinder et al. 2012; Ciais et al. 2013; Suddick et al. 2013). More efficient intervention pathways and methods should be found to mitigate the negative impacts of these abnormalities. Galloway et al. (2008) indicated four intervention pathways for alleviating excessive $\mathrm{Nr}$ emissions. First, the $\mathrm{Nr}$ emissions from fossil-fuel combustion may decrease by $72 \%$ (from $25 \mathrm{Tg} \mathrm{N} \mathrm{a}^{-1}$ to 7 $\operatorname{Tg~} \mathrm{N} \mathrm{a}^{-1}$ ) when the maximum feasible reduction pathways are chosen in controlling $\mathrm{NO}_{\mathrm{x}}$ emissions from fossil-fuel combustion using reasonable currently available technologies (Galloway et al. 2008). Second, an increase in the nitrogen-uptake efficiency of crops by selecting species (Lu et al. 2014; Li et al. 2015) may reduce the $\mathrm{Nr}$ production of $c .15 \mathrm{Tg} \mathrm{N} \mathrm{a}^{-1}$. Third, the same reduction above may occur when appropriate animal management practices are applied. Fourth, $5 \mathrm{Tg} \mathrm{N}$ of $\mathrm{Nr}$ may be transformed into $\mathrm{N}_{2}$ by using sewage treatment systems in cities. Together, approximately $28 \%$ of the total $\mathrm{Nr}$ produced in $2005\left(187 \mathrm{Tg} \mathrm{N} \mathrm{a}{ }^{-1}\right)$ could be reduced by using these four intervention pathways (Galloway et al. 2008). Furthermore, more updated strategies and advanced methods are available for addressing urgent $\mathrm{N}$ management issues in 
484

485

486

487

488

489

490

491

492

493

494

495

496

497

498

499

500

501

502

503

504

505

506

agricultural and natural ecosystems. These strategies mainly include the following: (1) Finding a better N application rate to solve the excessive use of $\mathrm{N}$ in intensive agricultural ecosystems for both environmental and farmer's profit (Ju et al. 2009; Wang et al. 2011). (2) Selecting appropriate cultivars with higher NUE, higher productive capacities, and better grain quality (Lu et al. 2014). (3) Using advanced field cultivation management that can substantially enhance sustainable $\mathrm{N}$ use and mitigate $\mathrm{N}$ contamination due to overuse. For example, returning plant residues to the soil to promote soil $\mathrm{N}$ turnover (Chen et al. 2014a); the addition of moderate $\mathrm{N}$ concentrations and the use of deep sub-soiling practices during fallow periods to improve the soil water status and grain quality (e.g., high protein concentration in grain) (Sun et al. 2014); the use of precision agriculture techniques, such as precision planting technologies, to attain higher yields when using moderate $\mathrm{N}$ fertilizer application rates in wheat fields (Xu et al. 2013c); the use of conservation tillage (Mueller et al. 2012), optimization of N, P and K fertilizer application ratios (Mueller et al. 2012; Sun and Huang 2012), application of slow release fertilizer (e.g. Shaviv and Mikkelsen 1993; Ni et al. 2011); and optimization of irrigation regimes to reduce inorganic $\mathrm{N}$ movement, including the movement of nitrate into deep soil layers, to mitigate $\mathrm{N}$ contamination in the most intensive agricultural ecosystems (Wang et al. 2008) where $\mathrm{N}_{\mathrm{dep}}$ and the overuse of $\mathrm{N}$ fertilizers are substantial and common (Ju et al. 2009; Liu et al. 2013). (4) Extending more efficient cropping systems with low $\mathrm{N}$ use and decreased $\mathrm{N}$ pollution. For example, an agro-ecosystem that uses organic cropping systems with catch crops to decrease diffuse nitrogen pollution in some areas (Masilionyte et al. 2014); wheat/maize systems with lower $\mathrm{N}$ loss rates relative to rice/wheat systems (Ju et al. 2009); and an efficient integrated soil-crop management system for achieving sustainable intensification (Cui et al. 2014; Chen et al. 2014a). (5) Currently, biochemistry and genetic studies are alternative solutions for improving BNF in symbiotic systems, such as bean rhizobia, because they can employ biochemical technologies under climatic change conditions, such as elevated $\mathrm{CO}_{2}$ and water deficits (Fowler et al. 2013; Coleto et al. 2014). These solutions may lead to the optimization of nitrogen fertilizer 
507

508

509

510

511

512

513

514

515

516

517

518

519

520

521

522

523

524

525

526

527

528

529

application and subsequently maintain a positive N balance (Suddick et al. 2013). Finally, we should make great efforts to employ a feasible policy aiming at rising NUE to improve the nitrogen balance from regional to global scales. For instance, calculations of a nitrogen footprint would help one to track his contribution in the nitrogen balance of an ecosystem (N-Print 2016). Additionally, the creation of a network of experts from disciplines related to $\mathrm{N}$ dynamics and with the media can help us improve $\mathrm{N}$ management at regional and global scales such as the Research Coordination Network (RCN) or Reactive Nitrogen of North American Nitrogen Center (RCN 2016). Moreover, the use of some comprehensive environmental management methods, such as life cycle assessment (LCA), could help deal with $\mathrm{N}$ surplus issues in the ecosystem (Meier et al. 2015).

\section{Challenging issues}

There are several key issues that remain to be resolved including: (1) to explore underlying mechanisms of biochemical processes in $\mathrm{N}$ cycle driven by multiple climatic change factors such as warming, drought, and elevated $\mathrm{CO}_{2}$; (2) to assess the different contributions across nations or regions and integrate their $\mathrm{N}$ deposition rates globally; (3) to integrate, estimate and predict the changes in natural ecosystem structures and functions that face continually increasing anthropogenic $\mathrm{N}$ deposition at different spatial-temporal scales (e.g., from local, regional to global scales, Stevens et al. 2015) using both integrated experimental data and modelling methods; (4) to elucidate the associations of biodiversity in a given natural ecosystem with the abnormal N cycle dynamics induced by climatic change (Cardinale 2011; McDonnell et al. 2014); (5) to deal with wildfire impacts on the global $\mathrm{N}$ cycle and sustaining long-term vegetation productivity by altering available $\mathrm{N}$ under ongoing climate warming with the increases in the frequency and strength of the ecological disturbances like fire (Scholze et al. 2006; LeDuc et al. 2013; Pellegrini et al. 2015); (6) to measure and classify the extent to which environmental contamination is derived from N-rich ecosystems, 
and to assess the risks; (7) to find better intervention strategies to deal with $\mathrm{N}$ balance/cycling in the future (see above); (8) to compare processes of the $\mathrm{N}$ cycle between human managed (e.g. crop land) and natural ecosystems. Finally, how the $\mathrm{N}$ cycle interacts with biogeochemical cycle of other vital elements including C, $\mathrm{P}$, and $\mathrm{S}$ remains elusive, particularly at regional and global scales, requiring to be investigated in the future. Thus, these crucial knowledge gaps remain to be filled urgently.

\section{Conclusions}

In most regions throughout the world, particularly in regions within developing nations, the environment is experiencing severe air pollution, which is partially caused by anthropogenic $\mathrm{Nr}$ emissions (Vitousek et al. 1997; Galloway et al. 2008; Liu et al. 2013, 2016). Consequently, the $\mathrm{Nr}$ level predominately created by human activities will continue to increase with climate change and rapid socio-economic development, especially in developing countries. Thus, $\mathrm{Nr}$ pollution is becoming a severe environmental issue (Liu et al. 2013; Bassin et al. 2015). The anthropogenic acidification primarily induced by $\mathrm{N}$ emissions has resulted in an abnormal balance in the natural biogeochemical cycles of terrestrial ecosystems, which has resulted in severe ecological management and agricultural sustainability problems (Hoegh-Guldberg 2007; Bechmann et al. 2014). Additionally, excessive nitrogen inputs into the land represent another major cause of water and soil pollution worldwide, further exaggerating the vulnerability of ecosystems, including rapid losses in biodiversity and severe degradation of ecosystem function (Goulding et al. 1998; Ju et al. 2009; Canfield et al. 2010; Bassin et al. 2015). Particularly, climatic change may substantially alter the $\mathrm{N}$ balance and cycle linking the geosphere, biosphere and atmosphere, and produce considerable challenges and raise new concerns that threaten environmental security. Overall, nitrogen is a critical element that primarily controls species composition, functions, and biological dynamics of many terrestrial and aquatic ecosystems (Vitousek et al. 1997). Thus, stabilizing nitrogen levels within an appropriate range in terrestrial ecosystems 
553 and watersheds by mitigation pathways for the $\mathrm{N}$ management is one priority of ecological and

554 environmental research, and management policies and practices (Masilionytè et al. 2014; Bechmann et al.

555 2014; Meier et al. 2015; Thomas et al. 2015).

556

557

\section{Acknowledgments}

558

559

560

561

562

563

564

565

566

567

568

569

570

571

572

573

574

575

576

577

578

579

580

The study was funded jointly by the National Natural Science Foundation of China (41330531, 31170456) and China Special Fund for Meteorological Research in the Public Interest (Major projects) (GYHY201506001-3).

\section{References}

Aber, J., McDowell, W., Nadelhoffer, K., Magill, A., Berntson, G., Kamakea M, et al. 1998. Nitrogen saturation in temperate forest ecosystems. BioScience 48(11):921-934. doi:10.2307/1313296.

Aber, J.D., Nadelhoffer, K.J., Steudler, P., and Melillo, J.M. 1989. Nitrogen saturation in northern forest ecosystems. BioScience 39(6):378-386. doi: 10.2307/1311067.

Adachi, M., Hasegawa, T., Fukayama, H., Tokida, T., Sakai, H., Matsunami, T., et al. 2014. Soil and water warming accelerates phenology and down-regulation of leaf photosynthesis of rice plants grown under free-air $\mathrm{CO}_{2}$ enrichment (FACE). Plant Cell Physiol. 55(2):370-380. doi:10.1093/pcp/pcu005.

Bai, Y., Wu, J., Clark, C.M., Naeem, S., Pan, Q., Huang, J., Zhang, L., and Han, X. 2010. Tradeoffs and thresholds in the effects of nitrogen addition on biodiversity and ecosystem functioning: evidence from inner Mongolia Grasslands. Global Change Biol. 16(1):358-372. doi:10.1111/j.1365-2486.2009.01950.x.

Baron, J.S., Hall, E.K., Nolan, B.T., Finlay, J.C., Bernhardt, E.S., Harrison, J.A., et al. 2013. The interactive effects of excess reactive nitrogen and climate change on aquatic ecosystems and water resources of the United States. Biogeochemistry 114(1):71-92. doi:10.1007/s10533-012-9788-y.

Bassin, S., Käch, D., Valsangiacomo, A., Mayer, J., Oberholzer, H.-R., Volk, M., and Fuhrer, J. 2015. Elevated ozone and nitrogen deposition affect nitrogen pools of subalpine grassland. Environ. Pollut. 201:67-74. doi:10.1016/j.envpol.2015.02.038.

Bechmann, M., Blicher-Mathiesen, G., Kyllmar, K., Iital, A., Lagzdins, A., and Salo, T. 2014. Nitrogen application, balances and their effect on water quality in small catchments in the Nordic-Baltic countries. 
581

582

583

584

585

586

587

588

589

590

591

592

593

594

595

596

597

598

599

600

601

602

603

604

605

606

607

608

609

610

Agr. Ecosyst. Environ. 198:104-113. doi:10.1016/j.agee.2014.04.004.

Bloom, A.J., Asensio, J.S.R., Randall, L., Rachmilevitch, S., Cousins, A.B., and Carlisle, E.A. 2012. CO 2 enrichment inhibits shoot nitrate assimilation in $\mathrm{C}_{3}$ but not $\mathrm{C}_{4}$ plants and slows growth under nitrate in $\mathrm{C}_{3}$ plants. Ecology 93(2):355-367. doi:10.1890/11-0485.1.

Bloom, A.J., Burger, M., Kimball, B.A., and Pinter Jr.P.J. 2014. Nitrate assimilation is inhibited by elevated $\mathrm{CO}_{2}$ in field-grown wheat. Nat. Clim. Change 4:477-480. doi:10.1038/nclimate2183.

Bobbink, R., Hicks, K., Galloway, J., Spranger, T., Alkemade, R., Ashmore, M., Bustamante, M., Cinderby, S., Davidson, E., and Dentener, F. 2010. Global assessment of nitrogen deposition effects on terrestrial plant diversity: a synthesis. Ecol. Appl. 20(1):30-59. doi:10.1890/08-1140.1.

Bobbink, R., Hornung, M., and Roelofs, J.G. 1998. The effects of air-borne nitrogen pollutants on species diversity in natural and semi-natural European vegetation. J. Ecol. 86(5):717-738. doi:10.1046/j.1365-2745.1998.8650717.x.

Bouwman, A.F., Beusen, A.H.W., Griffioen, J., Van Groenigen, J.W., Hefting, M.M., Oenema, O., et al. 2013. Global trends and uncertainties in terrestrial denitrification and $\mathrm{N}_{2} \mathrm{O}$ emissions. Philos. Trans. R. Soc. B.-Biol. Sci. 368:20130112. doi:10.1098/rstb.2013.0112.

Bowman, W.D., Cleveland, C.C., Halada, L., Hreško, J., and Baron, J.S. 2008. Negative impact of nitrogen deposition on soil buffering capacity. Nat. Geosci. 1:767-770. doi:10.1038/ngeo339.

Bracken, M.E.S., and Stachowicz, J.J. 2006. Seaweed diversity enhances nitrogen uptake via complementary use of nitrate and ammonium. Ecology 87(9):2397-2403. doi:10.1890/0012-9658(2006)87.

Bernal, S., Hedin, L.O., Likens, G.E., Gerber, S., and Buso, D.C. 2012. Complex response of the forest nitrogen cycle to climate change. Proc. Natl. Acad. Sci. USA 109(9):3406-3411. doi:10.1073/pnas.112144810.

Canfield, D.E., Glazer, A.N., and Falkowski, P.G. 2010. The evolution and future of Earth's nitrogen cycle. Science 330(6001):192-196. doi:10.1126/science.1186120.

Cardinale, B. 2011. Biodiversity improves water quality through niche partitioning. Nature 472:86-89. doi:10.1038/nature09904.

Carrillo, Y., Dijkstra, F.A., Pendall, E., LeCain, D., and Tucker, C. 2014. Plant rhizosphere influence on microbial $\mathrm{C}$ metabolism, the role of elevated $\mathrm{CO}_{2}, \mathrm{~N}$ availability and root stoichiometry. Biogeochemistry 117(2):229-240. doi:10.1007/s10533-014-9954-5.

Chapman, S.K., Devine, K.A., Curran, C., Jones, R.O., and Gilliam, F.S. 2015. Impacts of soil nitrogen and 
611

612

613

614

615

616

617

618

619

620

621

622

623

624

625

626

627

628

629

630

631

632

633

634

635

636

637

638

639

640

carbon additions on forest understory communities with a long nitrogen deposition history. Ecosystems doi:10.1007/s10021-015-9922-5.

Charles, H., and Dukes, J.S. 2009. Effects of warming and altered precipitation on plant and nutrient dynamics of a New England salt marsh. Ecol. Appl. 19(7):1758-1773. doi:10.1890/08-0172.1.

Chen, A., Lei, B., Hu, W., Lu, Y., Mao, Y., Duan, Z., and Shi, Z. 2015a. Characteristics of ammonia volatilization on rice grown under different nitrogen application rates and its quantitative predictions in Erhai Lake Watershed, China. Nutr. Cycl. Agroecosys. 101(1):139-152. doi:10.1007/s10705-014-9660-7

Chen, B., Liu, E., Tian, Q., Yan, C., and Zhang, Y. 2014a. Soil nitrogen dynamics and crop residues, a review. Agron. Sustain. Dev. 34(2):429-442. doi:10.1007/s13593-014-0207-8.

Chen, D., Lan, Z., Hu, S., and Bai, Y. 2015b. Effects of nitrogen enrichment on belowground communities in grassland: Relative role of soil nitrogen availability vs. soil acidification. Soil Biol. Biochem. 89:99-108. doi:10.1016/j.soilbio.2015.06.028.

Chen, J., and Stark, J.M. 2000. Plant species effects and carbon and nitrogen cycling in a sagebrush-crested wheatgrass soil. Soil Biol. Biochem. 32(1):47-57. doi:10.1016/S0038-0717(99)00124-8.

Chen, J., Wang, C., Wu, F.-H., Wang, W.-H., Liu, T.-W., and Chen, J. 2015c. Variation of nitric oxide emission potential in plants: a possible link to leaf $\mathrm{N}$ content and net photosynthetic activity. J. Plant Ecol. 8(3):313-320. doi: 10.1093/jpe/rtu015.

Chen, X., Cui, Z., Fang, M., Vitousek, P., Zhao, M., Ma, W., et al. 2014b. Producing more grain with lower environmental costs. Nature 514:486-489. doi:10.1038/nature13609.

Chen, X.P., Cui, Z.L., Vitousek, P.M., Cassman, K.G., Matson, P.A., Bao, J.S., et al. 2011a. Integrated soilcrop system management for food security. Proc. Natl. Acad. Sci. USA 108(16):6399-6404.

Chen, Y.T., Borken, W., Stange, C.F., and Matzner, E. 2011b. Effects of decreasing water potential on gross ammonification and nitrification in an acid coniferous forest soil. Soil Biol. Biochem. 43(2):333-338. doi:10.1016/j.soilbio.2010.10.020.

Cheng, L., Booker, F.L., Tu, C., Burkey, K.O., Zhou, L., Shew, H.D., Rufty, T.W., and Hu, S. 2012 Arbuscular mycorrhizal fungi increase organic carbon decomposition under elevated $\mathrm{CO}_{2}$. Science 337:1084-1087.

Ciais, P., Sabine, C., Bala, G., Bopp, L., Brovkin, V., Canadell, J., Chhabra, A., DeFries, R., Galloway, J., Heimann, M., Jones, C., Le Quéré, C., Myneni, R.B., Piao, S., and Thornton, P. 2013. Carbon and other biogeochemical Cycles. In Climate Change 2013: The Physical Science Basis. Contribution of Working 
641

642

643

644

645

646

647

648

649

650

651

652

653

654

655

656

657

658

659

660

661

662

663

664

665

666

667

668

669

670

Group I to the Fifth Assessment Report of the Intergovernmental Panel on Climate Change. Edited by Stocker, T.F., Qin, D., Plattner, G.-K., Tignor, M., Allen, S.K., Boschung, J., Nauels, A., Xia, Y., Bex, V., and Midgley, P.M. Cambridge University Press, Cambridge, United Kingdom and New York, NY, USA.

Clark, C.M., and Tilman, D. 2008. Loss of plant species after chronic low-level nitrogen deposition to prairie grasslands. Nature 451:712-715. doi:10.1038/nature06503.

Coleto, I., Pineda, M., Rodiño, A.P., De Ron, A.M., and Alamillo, J.M. 2014. Comparison of inhibition of $\mathrm{N}_{2}$ fixation and ureide accumulation under water deficit in four common bean genotypes of contrasting drought tolerance. Ann. Bot. 113(6):1071-1082. doi: 10.1093/aob/mcu029.

Conroy, J.P. 1992. Influence of elevated atmospheric $\mathrm{CO}_{2}$ concentrations on plant nutrition. Aust. J. Bot. 40(5):445-456. doi:10.1071/BT9920445.

Cotrufo, F., Ineson, P., and Scott, A.Y. 1998. Elevated $\mathrm{CO}_{2}$ reduces the nitrogen concentration of plant tissues. Global Change Biol. 4(1):43-54. doi:10.1046/j.1365-2486.1998.00101.x.

Cui, Z., Dou, Z., Chen, X., Ju, X., and Zhang, F. 2014. Managing agricultural nutrients for food security in China: past, present, and future. Agron. J. 106(1):191-198. doi:10.2134/agronj2013.0381.

Davey, P.A., Parsons, A.J., Atkinson, L., Wadge, K., and Long, S.P. 1999. Does photosynthetic acclimation to elevated $\mathrm{CO}_{2}$ increase photosynthetic nitrogen-use efficiency? A study of three native UK grassland species in open-top chambers. Funct. Ecol. 13(1):21-28. doi:10.1046/j.1365-2435.1999.00004.x.

Davidson, E.A., Carvalho, C.J.R., Figueira, A.M., Ishida, F.Y., Ometto, J.P.H.B., Nardoto, G.B., et al. 2007. Recuperation of nitrogen cycling in Amazonian forests following agricultural abandonment. Nature 447:995-998. doi:10.1038/nature05900.

Davidson, E.A., Chorover, J., and Dail, D.B. 2003. A mechanism of abiotic immobilization of nitrate in forest ecosystems, the ferrous wheel hypothesis. Global Change Biol. 9(2):228-236. doi:10.1046/j.1365-2486.2003.00592.x.

Davies, J. A. C., Tipping, E., Rowe, E. C., Boyle, J. F., Graf, P.E., and Martinsen, V. 2016. Long-term P weathering and recent $\mathrm{N}$ deposition control contemporary plant-soil $\mathrm{C}, \mathrm{N}$ and P. Glob. Biogeochem. Cycles. doi:10.1002/2015GB005167.

de Klein, C.A.M., Shepherd, M.A., and van der Weerden, T.J. 2015. Nitrous oxide emissions from grazed grasslands: interactions between the N cycle and climate change - a New Zealand case study. Curr. Opin. Env. Sust. 9(SI):131-139. doi:10.1016/j.cosust.2014.09.016.

Delgado-Baquerizo, M., Maestre, F.T., Gallardo, A., Bowker, M.A., Wallenstein, M.D., Quero, J.L., et al. 
671

672

673

674

675

676

677

678

679

680

681

682

683

684

685

686

687

688

689

690

691

692

693

694

695

696

697

698

699

700

2013. Decoupling of soil nutrient cycles as a function of aridity in global drylands. Nature 502:672-676. doi:10.1038/nature12670.

Deng, L., Wang, K.B., and Shangguan, Z.P. 2014. Long-term natural succession improves nitrogen storage capacity of soil on the Loess Plateau, China. Soil Res. 52(3):262-270. doi:10.1071/SR12377.

Dentener, F., Drevet, J., Lamarque, J.F., Bey, I., Eickhout, B., Fiore, A.M., et al. 2006. Nitrogen and sulfur deposition on regional and global scales, a multimodel evaluation. Glob. Biogeochem. Cycles 20. doi:10. 1029/2005GB002672.

Dentener, F.J., and Crutzen, P.J. 1994. A three-dimensional model of the global ammonia cycle. J. Atmos. Chem. 19(4):331-369. doi:10.1007/BF00694492

Dintwe, K., Okin, G.S., D’Odorico, P., Hrast, T., Mladenov, N., Handorean, A., Bhattachan, A., and Caylor, K.K. 2015. Soil organic C and total N pools in the Kalahari: potential impacts of climate change on C sequestration in savannas. Plant Soil 396(1):27-44. doi:10.1007/s11104-014-2292-5.

Du, Y., Guo, P., Liu, J., Wang, C., Yang, N., and Jiao, Z. 2014. Different types of nitrogen deposition show variable effects on the soil carbon cycle process of temperate forests. Global Change Biol. 20(10):3222-3228. doi:10.1111/gcb.12555.

Durand, P., Moreau, P., Salmon-Monviola, J., Ruiz, L., Vertes, F., and Gascuel-Odoux, C. 2015. Modelling the interplay between nitrogen cycling processes and mitigation options in farming catchments. J. Agr. Sci. 153(6):959-974. doi:10.1017/S0021859615000258.

Elbert, W., Weber, B., Burrows, S., Steinkamp, J., Büdel, B., Andreae, M.O., and Pöschl, U. 2012. Contribution of cryptogamic covers to the global cycles of carbon and nitrogen. Nat. Geosci. 5:459-462. doi:10.1038/ngeo1486.

Fang, J., Kato, T., Guo, Z., Yang, Y., Hu, H., Shen, H., et al. 2014. Evidence for environmentally enhanced forest growth. Proc. Natl. Acad. Sci. USA 111(26):9527-9532. doi:10.1073/pnas.1402333111.

Farage, P.K., McKee, I.F., and Long, S.P. 1998. Does a low nitrogen supply necessarily lead to acclimation of photosynthesis to elevated $\mathrm{CO}_{2}$ ? Plant Physiol. 118(2):573-580. doi:10.1104/pp.118.2.573.

Feng, Z., Rütting, T., Pleijel, H., Wallin, G., Reich, P., et al. 2015. Constraints to nitrogen acquisition of terrestrial plants under elevated $\mathrm{CO}_{2}$. Global Change Biol 21(8):3152-3168. doi:10.1111/gcb.12938.

Finzi, A.C., Austin, A.T., Cleland, E.E., Frey, S.D., Houlton, B.Z., and Wallenstein, M.D. 2011. Responses and feedbacks of coupled biogeochemical cycles to climate change, examples from terrestrial ecosystems. Front. Ecol. Environ. 9(1):61-67. doi:10.1890/100001. 
701

702

703

704

705

706

707

708

709

710

711

712

713

714

715

716

717

718

719

720

721

722

723

724

725

726

727

728

729

730

Fowler, D., Pyle, J.A., Raven, J.A., and Sutton, M.A. 2013. The global nitrogen cycle in the twenty-first century, introduction. Philos Trans R Soc B-Biol Sci 368. doi:10.1098/rstb.2013.0165.

Galloway, J.N., Townsend, A.R., Erisman, J.W., Bekunda, M., Cai, Z., Freney, J.R., et al. 2008. Transformation of the nitrogen cycle, recent trends, questions, and potential solutions. Science 320(5878):889-892. doi:10.1126/science.1136674.

Gerber, S., Hedin, L.O., Oppenheimer, M., Pacala, S.W., and Shevliakova, E. 2010. Nitrogen cycling and feedbacks in a global dynamic land model. Glob. Biogeochem. Cycles 24. doi:10.1029/2008GB003336.

Gestel, N.C., Schwilk, D.W., Tissue, D.T., and Zak, J.C. 2011. Reductions in daily soil temperature variability increase soil microbial biomass $\mathrm{C}$ and decrease soil $\mathrm{N}$ availability in the Chihuahuan Desert, potential implications for ecosystem C and N fluxes. Global Change Biol 17(2):3564-3576. doi:10.1111/j.1365-2486.2011.02479.x.

Goulding, K.W.T., Bailey, N.J., Bradbury, N.J., Hargreaves, P., Howe, M., Murphy, D.V., et al. 1998. Nitrogen deposition and its contribution to nitrogen cycling and associated soil processes. New Phytol. 139(1):49-58. doi:10.1046/j.1469-8137.1998.00182.x.

Gruber, N., and Galloway, J.N. 2008. An Earth-system perspective of the global nitrogen cycle. Nature 451:293-296. doi:10.1038/nature06592.

Gundersen, P., Emmett, B.A., Kjønaas, O.J., Koopmans, C.J., and Tietema, A. 1998. Impact of nitrogen deposition on nitrogen cycling in forests: a synthesis of NITREX data. Forest Ecol. Manag. 101(1-3):37-55. doi:10.1016/S0378-1127(97)00124-2.

Guo, J.H., Liu, Y.Z., Zhang, Y., Shen, L., Han, W.X., and Zhang, W.F., et al. 2010. Significant acidification in major Chinese croplands. Science 327(5968):1008-1010. doi:10.1126/science.1182570.

Gutiérrez, D., Morcuende, R., Del Pozo, A., Martínez-Carrasco, R., and Pérez, P. 2013. Involvement of nitrogen and cytokinins in photosynthetic acclimation to elevated $\mathrm{CO}_{2}$ of spring wheat. J. Plant Physiol. 170(15):1337-1343. doi:10.1016/j.jplph.2013.05.006.

He, C.E., Liu, X.J., Fangmeier, A., and Zhang, F.S. 2007. Quantifying the total airborne nitrogen input into agroecosystems in the North China Plain. Agr. Ecosyst. Environ. 121(4):395-400. doi:10.1016/j.agee.2006.12.016.

Hodge, A., and Storer, K. 2015. Arbuscular mycorrhiza and nitrogen: implications for individual plants through to ecosystems. Plant Soil 386(1):1-19. doi:10.1007/s11104-014-2162-1.

Hoegh-Guldberg, O., Mumby, P.J., Hooten, A.J., Steneck, R.S., Greenfield, P., Gomez, E., et al. 2007. Coral 
731

732

733

734

735

736

737

738

739

740

741

742

743

744

745

746

747

748

749

750

751

752

753

754

755

756

757

758

759

760

reefs under rapid climate change and ocean acidification. Science 318(5857):1737-1742. doi:10.1126/science.1152509.

Hu, S., Chapin, F.S., Firestone, M.K., Field, C.B., and Chiariello, N.R. 2001. Nitrogen limitation of microbial decomposition in a grassland under elevated $\mathrm{CO}_{2}$. Nature 409 (6817):188-191. doi:10.1038/35051576.

Huang, S., Bartlett, P., and Arain, M. A. 2016. Assessing nitrogen controls on carbon, water and energy exchanges in major plant functional types across North America using a carbon and nitrogen coupled ecosystem model. Ecol. Model. 323:12-27. doi:10.1016/j.ecolmodel.2015.11.020.

Hyvönen, R., Ågren, G.I., Linder, S., Persson, T., Cotrufo, M.F., Ekblad, A., et al. 2007. The likely impact of elevated $\left[\mathrm{CO}_{2}\right]$, nitrogen deposition, increased temperature and management on carbon sequestration in temperate and boreal forest ecosystems, a literature review. New Phytol. 173(3):463-480. doi:10.1111/j.1469-8137.2007.01967.x.

Jackson, L.E., Strauss, R.B., Firestone, M.K., and Bartolome, J.W. 1988. Plant and soil nitrogen dynamics in California annual grassland. Plant Soil 110(1):9-17. doi:10.1007/BF02143533.

Jia, Y., Yu, G., He, N., Zhan, X., Fang, H., Sheng, W., Zuo, Y., Zhang, D., and Wang, Q. 2013. Spatial and decadal variations in inorganic nitrogen wet deposition in China induced by human activity. Sci. Rep. 4: 3763. doi:10.1038/srep03763.

Ju, X.T., Xing, G.X., Chen, X.P., Zhang, S.L., Zhang, L.J., and Liu, X.J., et al. 2009. Reducing environmental risk by improving $\mathrm{N}$ management in intensive Chinese agricultural systems. Proc. Natl. Acad. Sci. USA 106:3041-3046.

Kardol, P., De Long, J.R., and Sundqvist, M.K. 2012. Crossing the threshold: the power of multi-level experiments in identifying global change responses. New Phytol. 196(2):323-326. doi:10.1111/j.1469-8137.2012.04341.x.

Khan, M.A.S.A., Grant, K., Beierkuhnlein, C., Kreyling, J., and Jentsch, A. 2014. Climatic extremes lead to species-specific legume facilitation in an experimental temperate grassland. Plant Soil 379(1-2):161-175. doi:10.1007/s11104-014-2050-8

Kopáček, J., Cosby, B.J., Evans, C.D., Hruška, J., Moldan, F., Oulehle F, et al. 2013. Nitrogen, organic carbon and sulphur cycling in terrestrial ecosystems, linking nitrogen saturation to carbon limitation of soil microbial processes. Biogeochemistry 115(1-3):33-51. doi:10.1007/s10533-013-9892-7.

Lam, H.M., Coschigano, K.T., Oliveira, I.C., Melo-Oliveira, R., and Coruzzi, G.M. 1996. The molecular 
761

762

763

764

765

766

767

768

769

770

771

772

773

774

775

776

777

778

779

780

781

782

783

784

785

786

787

788

789

790

genetics of nitrogen assimilation into amino acids in higher plants. Annu. Rev. Plant Physiol. Plant Mol. Biol. 47:569-593. doi:10.1146/annurev.arplant.47.1.569.

Larsen, K.S., Andresen, L.C., Beier, C., Jonasson, S., Albert, K.R., Ambus, P.E.R., et al. 2011. Reduced N cycling in response to elevated $\mathrm{CO}_{2}$, warming, and drought in a Danish heathland, synthesizing results of the CLIMAITE project after two years of treatments. Global Change Biol. 17(5):1884-1899. doi:10.1111/j.1365-2486.2010.02351.x.

Leakey, A.D., Uribelarrea, M., Ainsworth, E.A., Naidu, S.L., Rogers, A., Ort, D.R., and Long, S.P. 2006. Photosynthesis, productivity, and yield of maize are not affected by open-air elevation of $\mathrm{CO}_{2}$ concentration in the absence of drought. Plant Physiol. 140(2):779-790. doi:10.1104/pp.105.073957.

Li, X., Zeng, R., and Liao, H. 2015. Improving crop nutrient efficiency through root architecture modifications. J. Integr. Plant Biol. doi:10.1111/jipb.12434.

Li ,Y., Yu, S., Strong, J., and Wang, H. 2012. Are the biogeochemical cycles of carbon, nitrogen, sulfur, and phosphorus driven by the "FeIII-FeII redox wheel" in dynamic redox environments? J. Soils Sediments 12(5):683-693. doi:10.1007/s11368-012-0507-z.

Liu, J., Huang, W., Zhou, G., Zhang, D., Liu, S., and Li, Y. 2013. Nitrogen to phosphorus ratios of tree species in response to elevated carbon dioxide and nitrogen addition in subtropical forests. Global Change Biol. 19(1):208-216. doi:10.1111/gcb.12022.

Liu, T., Xu, Z.Z., Hou, Y.H., and Zhou, G.S. 2015. Effects of warming and changing precipitation rates on soil respiration over two years in a desert steppe of northern China. Plant Soil doi:10.1007/s11104-015-2705-0.

Liu, W., Jiang, L., Hu, S., Li, L., Liu, L., and Wan, S. 2014. Decoupling of soil microbes and plants with increasing anthropogenic nitrogen inputs in a temperate steppe. Soil Biol. Biochem. 72:116-122. doi:10.1016/j.soilbio.2014.01.022.

Liu, X., Zhang, Y., Han, W., Tang, A., Shen, J., Cui, Z., Vitousek, P., Erisman, J.W., Goulding, K., Christie, P., Fangmerer, A., and Zhang, F. 2014. Enhanced nitrogen deposition over China. Nature 494(7438):459-462. doi: $10.1038 /$ nature11917.

Liu, Z., Hu, B., Zhang, J., Yu, Y., and Wang, Y. 2016. Characteristics of aerosol size distributions and chemical compositions during wintertime pollution episodes in Beijing. Atmos. Res. 168:1-12. doi:10.1016/j.atmosres.2015.08.013.

Lu, D., Lu, F., Yan, P., Cui, Z., and Chen, X. 2014. Elucidating population establishment associated with N 
791

792

793

794

795

796

797

798

799

800

801

802

803

804

805

806

807

808

809

810

811

812

813

814

815

816

817

818

819

820

management and cultivars for wheat production in China. Field Crops Res. 163:81-89. doi:10.1016/j.fcr.2014.03.022.

Luo, Y., Hui, D., and Zhang, D. 2006. Elevated $\mathrm{CO}_{2}$ stimulates net accumulations of carbon and nitrogen in land ecosystems, a meta-analysis. Ecology 87(1):53-63. doi:10.1890/04-1724.

Luo, Y., Su, B., Currie, W.S., Dukes, J.S., Finzi, A., Hartwig, U., et al. 2004. Progressive nitrogen limitation of ecosystem responses to rising atmospheric carbon dioxide. Bioscience 54(8):731-739. doi:10.1641/0006-3568(2004)054[0731:PNLOER]2.0.CO;2.

Malik, A., and Tauler, R. 2015. Exploring the interaction between $\mathrm{O}_{3}$ and $\mathrm{NO}_{\mathrm{x}}$ pollution patterns in the atmosphere of Barcelona, Spain using the MCR-ALS method. Sci. Total Environ. 517:151-161. doi:10.1016/j.scitotenv.2015.01.105.

Masilionyte, L., Maikštenienè, S., Velykis, A., and Satkus, A. 2014. Agroecosystems to decrease diffuse nitrogen pollution in Northern Lithuania. J. Environ. Eng. Landscape Manage. 22(3):194-207. doi:10.3846/16486897.2013.860898.

McDonnell, T.C., Belyazid, S., Sullivan, T.J., Sverdrup, H., Bowmand, W.D., and Porter, E.M. 2014. Modeled subalpine plant community response to climate change and atmospheric nitrogen deposition in Rocky Mountain National Park, USA. Environ. Pollut. 187:55-64. doi:10.1016/j.envpol.2013.12.021.

McGill, W.B., and Cole, C.V. 1981. Comparative aspects of cycling of organic C, N, S and P through soil organic matter. Geoderma 26(4):267-286. doi:10.1016/0016-7061(81)90024-0.

Meier, M.S., Stoessel, F., Jungbluth, N., Juraske, R., Schader, C., and Stolze, M. 2015. Environmental impacts of organic and conventional agricultural products - Are the differences captured by life cycle assessment? J. Environ. Manage. 149:193-208. doi:10.1016/j.jenvman.2014.10.006.

Meng, J. 2012. Nitrous oxide emission in Anammox reactor. M.Sc. thesis, Iowa State University, Ames, Iowa.

Mo, J., Zhang, W.E.I., Zhu, W., Gundersen, P.E.R., Fang, Y., Li, D., and Wang, H.U.I. 2008. Nitrogen addition reduces soil respiration in a mature tropical forest in southern China. Global Change Biol. 14:403-412. doi: 10.1111/j.1365-2486.2007.01503.x.

Moffat, A.S. 1998. Global nitrogen overload problem grows critical. Science 279 (5353):988-989. doi:10.1126/science.279.5353.988.

Mueller, N.D., Gerber, J.S., Johnston, M., Ray, D.K., Ramankutty, N., and Foley, J.A. 2012. Closing yield gaps through nutrient and water management. Nature 490(7419):254-257. doi:10.1038/nature11420. 
821

822

823

824

825

826

827

828

829

830

831

832

833

834

835

836

837

838

839

840

841

842

843

844

845

846

847

848

849

850

N-Print. 2016. Country N Footprints [online]. Available from http://www.n-print.org/CountryNFootprints [accessed 12 January 2016].

Neeru, M., Sawhney, S.K., and Veena, S. 1998. Ferricyanide restores nitrate reductase activity in leaf extracts of water stressed wheat seedling. J. Plant Physiol. 52(4-5):577-579. doi:10.1016/S0176-1617(98)80280-0.

Ni, B., Liu, M., Lü, S., Xie, L., and Wang, Y. 2011. Environmentally friendly slow-release nitrogen fertilizer. J. Agr. Food Chem. 59(18):10169-10175. doi:10.1021/jf202131z.

Noormets, A., Epron, D., Domec, J.C., McNulty, S.G., Fox, T., Sun, G., and King, J.S. 2015. Effects of forest management on productivity and carbon sequestration: A review and hypothesis. Forest Ecol. Manage. 355(SI):124-140. doi:10.1016/j.foreco.2015.05.019.

O’Neill, E.G. 1995. Responses of soil biota to elevated atmospheric carbon dioxide. In Belowground responses to rising atmospheric $\mathrm{CO}_{2}$ : implications for plants, soil biota, and ecosystem processes. Edited by P.S. Curtis, E.G. O’Neill, J. Teeri, A.D.R. Zak, and K.S. Pregitzer. Springer, Netherlands, pp. 55-65.

Oris, F., Asselin, H., Ali, A. A., Finsinger, W., and Bergeron, Y. 2014. Effect of increased fire activity on global warming in the boreal forest. Environ. Rev. 22(3): 206-219. doi:10.1139/er-2013-0062.

Paulot, F., Jacob, D.J., and Henze, D.K. 2013. Sources and processes contributing to nitrogen deposition, an adjoint model analysis applied to biodiversity hotspots worldwide. Environ. Sci. Technol. 47(7):3226-3233. doi: 10.1021/es3027727.

Pellegrini, A. F., Hedin, L. O., Staver, A. C., and Govender, N. 2015. Fire alters ecosystem carbon and nutrients but not plant nutrient stoichiometry or composition in tropical savanna. Ecology 96(5):1275-1285. doi:10.1890/14-1158.1.

Peñuelas, J., Sardans, J., Estiarte, M., Ogaya, R., Carnicer, J., and Coll, M et al. 2013. Evidence of current impact of climate change on life: a walk from genes to the biosphere. Global Change Biol. 19(8):2303-2338. doi:10.1111/gcb.12143.

Pinder, R.W., Davidson, E.A., Goodale, C.L., Greaver, T.R., Herrick, J.D., and Liu, L. 2012. Climate change impacts of US reactive nitrogen. Proc. Natl. Acad. Sci. USA 109(20):7671-7675. doi: 10.1073/pnas.1114243109.

RCN. 2016. Research coordination network on reactive nitrogen [online]. Available from http://nitrogennorthamerica.org/projects.html [accessed 12 January 2016].

Reay, D.S., Dentener, F., Smith, P., Grace, J., and Feely, R.A. 2008. Global nitrogen deposition and carbon sinks. Nat. Geosci. 1(7):430-437. doi:10.1038/ngeo230. 
851

852

853

854

855

856

857

858

859

860

861

862

863

864

865

866

867

868

869

870

871

872

873

874

875

876

877

878

879

880

Reich, P.B., Hobbie, S.E., and Lee, T.D. 2014. Plant growth enhancement by elevated $\mathrm{CO}_{2}$ eliminated by joint water and nitrogen limitation. Nat. Geosci. 7(12):920-924. doi:10.1038/NGEO2284.

Reich, P.B., Peterson, D.W., Wedin, D.A., and Wrage, K. 2001. Fire and vegetation effects on productivity and nitrogen cycling across a forest-grassland continuum. Ecology 82(6):1703-1719. doi:10.1890/0012-9658(2001)082[1703:FAVEOP]2.0.CO;2.

Richter, M., Hartwig, U.A., Frossard, E., Nösberger, J., and Cadisch, G. 2003. Gross fluxes of nitrogen in grassland exposed to elevated atmospheric $\mathrm{pCO}_{2}$ for seven years. Soil Biol. Biochem. 35(10):1325-1335. doi:10.1016/S0038-0717(03)00212-8.

Riha, K.M., Michalski, G., Gallo, E.L., Lohse, K.A., Brooks, P.D., and Meixner, T. 2014. High atmospheric nitrate inputs and nitrogen turnover in semi-arid urban catchments. Ecosystems 17(8):1309-1325. doi:10.1007/s10021-014-9797-x.

Rogers, A., Ainsworth, E.A., and Leakey, A.D. 2009. Will elevated carbon dioxide concentration amplify the benefits of nitrogen fixation in legumes? Plant Physiol. 151(3):1009-1016. doi:10.1104/pp.109.144113.

Rustad, L.E.J.L., Campbell, J., Marion, G., Norby, R., Mitchell, M., Hartley, A., et al. 2001. A meta-analysis of the response of soil respiration, net nitrogen mineralization, and aboveground plant growth to experimental ecosystem warming. Oecologia 126(4):543-562. doi:10.1007/s004420000544.

Rütting, T., and Andresen, L.C. 2015. Nitrogen cycle responses to elevated $\mathrm{CO}_{2}$ depend on ecosystem nutrient status. Nutr. Cycl. Agroecosyst. 101(3):285-294. doi:10.1007/s10705-015-9683-8.

Salmon-Monviola, J., Moreau, P., Benhamou, C., Durand, P., Merot, P., Oehler, F., and Gascuel-Odoux, C. 2013. Effect of climate change and increased atmospheric $\mathrm{CO}_{2}$ on hydrological and nitrogen cycling in an intensive agricultural headwater catchment in western France. Climatic Change 120(1):433-447. doi: 10.1007/s10584-013-0828-y.

Scholze, M., Knorr, W., Arnell, N.W., and Prentice, I.C. 2006. A climate-change risk analysis for world ecosystems. Proc. Natl. Acad. Sci. USA 103(35):13116-13120. doi:10.1073/pnas.0601816103.

Shaviv, A., and Mikkelsen, R.L. 1993. Controlled-release fertilizers to increase efficiency of nutrient use and minimize environmental degradation-A review. Fert. Res. 35(1-2):1-12. doi:10.1007/BF00750215.

Sheng, W., Yu, G., Jiang, C., Yan, J., Liu, Y., Wang, S., et al. 2013. Monitoring nitrogen deposition in typical forest ecosystems along a large transect in China. Environ. Monit. Assess. 185(1):833-844. doi:10.1007/s10661-012-2594-0.

Sicher, R.C., and Bunce, J.A. 1997. Relationship of photosynthetic acclimation to changes of Rubisco 
881

882

883

884

885

886

887

888

889

890

891

892

893

894

895

896

897

898

899

900

901

902

903

904

905

906

907

908

909

910

activity in weld-grown winter wheat and barley during growth in elevated carbon dioxide. Photosynth. Res. 52(1):27-38. doi:10.1023/A:1005874932233.

Smeck, N.E. 1985. Phosphorus dynamics in soils and landscapes. Geoderma 36(3-4):185-199. doi: 10.1016/0016-7061(85)90001-1.

Sorensen, P.L., and Michelsen, A. 2011. Long-term warming and litter addition affects nitrogen fixation in a subarctic heath. Global Change Biol. 17(1):528-537. doi:10.1111/j.1365-2486.2010.02234.x.

Sun, M., Gao, Z.Q., Zhao, W.F., Ren, A.X., Deng, Y., and Miao, G.Y. 2014. Effect of subsoiling in fallow period and nitrogen application on soil moisture and grain protein accumulation in dryland wheat. Acta Agron. Sin. 40(7):1286-1295.

Stevens, C.J., Lind, E.M., Hautier, Y., Harpole, W.S., Borer, E.T., Hobbie, S., et al. 2015. Anthropogenic nitrogen deposition predicts local grassland primary production worldwide. Ecology 96(6):1459-1465. doi:10.1890/14-1902.1.

Suddick, E.C., Whitney, P., Townsend, A.R., and Davidson, E.A. 2013. The role of nitrogen in climate change and the impacts of nitrogen-climate interactions in the United States: foreword to thematic issue. Biogeochemistry 114(1):1-10. doi:10.1007/s10533-012-9795-z.

Sun, W., and Huang, Y. 2012. Synthetic fertilizer management for China's cereal crops has reduced $\mathrm{N}_{2} \mathrm{O}$ emissions since the early 2000s. Environ. Pollut. 160:24-27. doi:10.1016/j.envpol.2011.09.006.

Sun, Z., Liu, L., Ma, Y., Yin, G., Zhao, C., Zhang, Y., and Piao, S. 2014. The effect of nitrogen addition on soil respiration from a nitrogen-limited forest soil. Agr. Forest Meteorol. 197:103-110. doi:10.1016/j.agrformet.2014.06.010.

Sutton, M.A., Oenema, O., Erisman, J.W., Leip, A., van Grinsven, H.,Winiwarter, W. 2011. Too much of a good thing. Nature 472:159-161.

Sutton, M.A., Reis, S., Billen, G., Cellier, P., Erisman, J.W., and Mosier, A.R., et al. 2012. Nitrogen \& Global Change. Biogeosciences 9:1691-1693. doi: doi:10.5194/bg-9-1691-2012.

Taub, D.R., Miller, B., and Allen, H. 2008. Effects of elevated $\mathrm{CO}_{2}$ on the protein concentration of food crops: a meta-analysis. Global Change Biol. 14(3):565-575. doi:10.1111/j.1365-2486.2007.01511.x.

Thomas, R.Q., Brookshire, E.N.G., and Gerber, S. 2015. Nitrogen limitation on land: how can it occur in Earth system models? Global Change Biol. 21(5):1777-1793. doi:10.1111/gcb.12813.

Townsend, A.R., Cleveland, C.C., Asner, G.P., and Bustamante, M.M. 2007. Controls over foliar N:P ratios in tropical rain forests. Ecology 88(1):107-118. doi:10.1890/0012-9658. 
911

912

913

914

915

916

917

918

919

920

921

922

923

924

925

926

927

928

929

930

931

932

933

934

935

936

937

938

939

940

Vadez, V., Sinclair, T.R., Serraj, R., and Purcell, L.C. 2000. Manganese application alleviates the water deficit-induced decline of $\mathrm{N}_{2}$ fixation. Plant Cell Environ 23(5):497-505. doi:10.1046/j.1365-3040.2000.00562.x.

van Groenigen, K.J., Qi, X., Osenberg, C.W., Luo, Y., and Hungate, B.A. 2014. Faster decomposition under increased atmospheric $\mathrm{CO}_{2}$ limits soil carbon storage. Science 344(6183):508-509. doi: 10.1126/science.1249534.

Vestergård, M., Dyrnum, K., Michelsen, A., Damgaard, C., and Holmstrup, M. 2015. Long-term multifactorial climate change impacts on mesofaunal biomass and nitrogen content. Appl. Soil Ecol. 92:54-63. doi:10.1016/j.apsoil.2015.03.002.

Vitousek, P.M., Aber, J.D., Howarth, R.W., Likens, G.E., Matson, P.A., Schindler, D.W., et al. 1997. Human alteration of the global nitrogen cycle: sources and consequences. Ecol. Appl. 7(3):737-750. doi10.1890/1051-0761(1997)007.

Wang, C., Butterbach-Bahl, K., He, N., Wang, Q., Xing, X., Han, X. 2015. Nitrogen addition and mowing affect microbial nitrogen transformations in a $\mathrm{C}_{4}$ grassland in northern China. Euro. J. Soil Sci. 66(3):485-495. doi: 10.1111/ejss.12231.

Wang, D., Xu, Z., Zhao, J., Wang, Y., and Yu, Z. 2011. Excessive nitrogen application decreases grain yield and increases nitrogen loss in a wheat-soil system. Acta Agric. Scand. Sect. B.-Soil Plant Sci. 61(8):681-692. doi:10.1080/09064710.2010.534108.

Wang, X.Y., He, M.R., Lu, Y.H., Zhang, H.H., Li, F., Hua, F.X., and Meng, S.H. 2008. Interactive effects of irrigation and nitrogen fertilizer on nitrogen fertilizer recovery and nitrate-N movement across soil profile in a winter wheat field. Acta Ecol. Sin. 28(2):685-694.

Wårlind, D., Smithl, B., Hickler, T., and Arneth, A. 2014. Nitrogen feedbacks increase future terrestrial ecosystem carbon uptake in an individual-based dynamic vegetation model. Biogeosciences 11(21):6131-6146. doi:10.5194/bgd-11-151-2014.

Wedin, D., and Tilman, D. 1996. Influence of nitrogen loading and species composition on the carbon balance of grasslands. Science 274(5293):1720-1723. doi:10.1126/science.274.5293.1720.

Wei, C., Yu, Q., Bai, E., Lü, X., Li, Q., Xia, J., et al. 2013. Nitrogen deposition weakens plant-microbe interactions in grassland ecosystems. Global Change Biol. 19(12):3688-3697. doi:10.1111/gcb.12348.

Wollenweber, B., Porter, J.R., and Schellberg, J. 2003. Lack of interaction between extreme high-temperature events at vegetative and reproductive stages in wheat. J. Agr. Crop Sci. 189(3):142-150. 
941

942

943

944

945

946

947

948

949

950

951

952

953

954

955

956

957

958

959

960

961

962

963

964

965

966

967

968

969

970

doi:10.1046/j.1439-037X.2003.00025.x.

Xia, J., Niu, S., and Wan, S. 2009. Response of ecosystem carbon exchange to warming and nitrogen addition during two hydrologically contrasting growing seasons in a temperate steppe. Global Change Biol. 15(6):1544-1556. doi:10.1111/j.1365-2486.2008.01807.x.

Xu, Z., Shimizu, H., Ito, S., Yagasaki, Y., Zou, C., Zhou, G., and Zheng, Y. 2014. Effects of elevated CO warming and precipitation change on plant growth, photosynthesis and peroxidation in dominant species from North China grassland. Planta 239(2):421-435. doi:10.1007/s00425-013-1987-9.

Xu, M., He, Z., Deng, Y., Wu, L., van Nostrand, J.D., Hobbie, S.E., Reich, P.B., and Zhou J. 2013a. Elevated $\mathrm{CO}_{2}$ influences microbial carbon and nitrogen cycling. BMC Microbiol. $13: 124$. doi:10.1186/1471-2180-13-124.

Xu, Z.Z., Shimizu, H., Yagasaki, Y., Ito, S., Zheng, Y.R., and Zhou, G.S. 2013b. Interactive effects of elevated $\mathrm{CO}_{2}$, drought, and warming on plants. J. Plant Growth Regul. 32(4):692-707. doi:10.1007/s00344-013-9337-5.

Xu, Z.Z., Yu, Z.W., and Zhao, J.Y. 2013c. Theory and application for the promotion of wheat production in China: past, present and future. J. Sci. Food Agr. 93(10):2339-2350. doi:10.1002/jsfa.6098.

Xu, Z.Z., and Yu, Z.W. 2005. Nitrogen accumulation and translocation for winter wheat under different irrigation regimes. J. Agron. Crop Sci. 191(6):439-449. doi: 10.1111/j.1439-037X.2005.00178.x.

Xu, Z.Z., Zhou, G.S., and Wang, Y.H. 2007. Combined effects of elevated $\mathrm{CO}_{2}$ and soil drought on carbon and nitrogen allocation of the desert shrub Caragana intermedia. Plant Soil 301(1):87-97. doi: 10.1007/s11104-007-9424-0.

Xu, Z.Z., and Zhou, G,S. 2006a. Combined effects of water stress and high temperature on photosynthesis, nitrogen metabolism and lipid peroxidation of a perennial grass Leymus chinensis. Planta 224(5):1080-1090. doi: 10.1007/s00425-006-0281-5.

Xu, Z.Z., and Zhou, G.S. 2006b. Nitrogen metabolism and photosynthesis in Leymus chinensis in response to long-term soil drought. J. Plant Growth Regul. 25(3):252-266. doi: 10.1007/s00344-006-0043-4.

Xu, Z.Z., and Zhou, G.S. 2004. Research advance in nitrogen metabolism of plant and its environmental regulation. J. Appl. Ecol. 15(3):511-516.

Xu, Z., Jiang, Y., and Zhou, G. 2015. Response and adaptation of photosynthesis, respiration, and antioxidant systems to elevated $\mathrm{CO}_{2}$ with environmental stress in plants. Front. Plant Sci. 6:701. doi: 10.3389/fpls.2015.00701. 
971

972

973

974

975

976

977

978

979

980

981

982

983

984

985

986

987

988

989

990

991

992

993

994

995

996

997

998

999

1000

Yan, J., Zhang, D., Liu, J., and Zhou, G. 2014. Interactions between $\mathrm{CO}_{2}$ enhancement and $\mathrm{N}$ addition on net primary productivity and water-use efficiency in a mesocosm with multiple subtropical tree species. Global Change Biol. 20(7):2230-2239. doi:10.1111/gcb.12501.

Yang, Y.H., Fang, J.Y., Ji, C.J., Datta, A., Li, P., Ma, W.H., Mohammat, A., Shen, H.H., Hu, H.F., Knapp, B.O., and Smith, P. 2014. Stoichiometric shifts in surface soils over broad geographical scales: evidence from China’s grasslands. Global Ecol. Biogeogr. 23(8):947-955. doi:10.1111/geb.12175.

Yang, Y.H., Ji, C.J., Ma, W.H., Wang, S.F., Wang, S.P., Han, W.X., Mohammat, A., Robinson, D., and Smith, P. 2012. Significant soil acidification across northern China's grasslands during 1980s-2000s. Global Change Biol. 18(7):2292-2300. doi:10.1111/j.1365-2486.2012.02694.x.

Yang, Y.H., Li, P., He, H.L., Zhao, X., Datta, A., Ma, W.H., Zhang, Y., Liu, X.J., Han, W.X., Wilson, M.C., and Fang, J.Y. 2015. Long-term changes in soil pH across major forest ecosystems in China. Geophys. Res. Lett. 42(3):933-940. doi:10.1002/2014GL062575.

Yoneyama, K., Xie, X., Kim, H.I., Kisugi, T., Nomura, T., Sekimoto, H., et al. 2012. How do nitrogen and phosphorus deficiencies affect strigolactone production and exudation? Planta 235(6):1197-1207. doi:10.1007/s00425-011-1568-8.

Yuan, Z.Y., Chen, H.Y.H. 2015. Decoupling of nitrogen and phosphorus in terrestrial plants associated with global changes. Nature Clim. Change 5, 465-469.

Yuan, Z.Y., Li, L.H., Han, X.G., Chen, S.P., Wang, Z.W., Chen, Q.S., and Bai, W.M. 2006. Nitrogen response efficiency increased monotonically with decreasing soil resource availability: a case study from a semiarid grassland in northern China. Oecologia 148(4):564-572. doi:10.1007/s00442-006-0409-0.

Zaehle, S. 2013. Terrestrial nitrogen-carbon cycle interactions at the global scale. Philos. Trans. R. Soc. B.-Biol. Sci. 368. doi:10.1098/rstb.2013.0125.

Zaehle, S., Jones, C.D., Houlton, B., Lamarque, J.F., and Robertson, E. 2015. Nitrogen availability reduces CMIP5 projections of twenty-first-century land carbon uptake. J. Clim. 28(6):2494-2511. doi: 10.1175/jcli-d-13-00776.1.

Zeng, J., Liu, X., Song, L., Lin, X., Zhang, H., Shen, C.., and Chu, H. 2016. Nitrogen fertilization directly affects soil bacterial diversity and indirectly affects bacterial community composition. Soil Biol. Biochem. 92:41-49. doi:10.1016/j.soilbio.2015.09.018.

Zhang, L., Huo, Y., Guo, D., Wang, Q., Bao, Y., and Li, L. 2014. Effects of multi-nutrient additions on GHG fluxes in a temperate grassland of northern China. Ecosystems 17(4):657-672. 
1001

1002

1003

1004

1005

1006

1007

1008

1009

1010

1011

1012

1013

1014

1015

1016

doi:10.1007/s10021-014-9750-z.

Zhang, L., Jacob, D.J., Knipping, E.M., Kumar, N., Munger, J.W., Carouge, C.C., et al. 2012. Nitrogen deposition to the United States: distribution, sources, and processes. Atmos. Chem. Phys. 12(10):45394554. doi:10.5194/acp-12-4539-2012.

Zhang, L., Wu, D., Shi, H., Zhang, C., Zhan, X., and Zhou, S. 2011. Effects of elevated $\mathrm{CO}_{2}$ and $\mathrm{N}$ addition on growth and $\mathrm{N}_{2}$ fixation of a legume subshrub (Caragana microphylla Lam.) in temperate grassland in China. PLoS One 6:e26842. doi:10.1371/journal.pone.0026842.

Zhang, N., Liu, W., Yang, H., Yu, X., Gutknecht, J.L., Zhang, Z., et al. 2013. Soil microbial responses to warming and increased precipitation and their implications for ecosystem C cycling. Oecologia 173(3):1125-1142. doi:10.1007/s00442-013-2685-9.

Zhang, Y., Lü, X., Isbell, F., Stevens, C., Han, X., He, N., et al. 2014. Rapid plant species loss at high rates and at low frequency of $\mathrm{N}$ addition in temperate steppe. Global Change Biol. 20(11):3520-3529. doi:10.1111/gcb.12611.

Zhou, S.M., Wang, C.Y., Zhang, Z.Y., and He, D.X. 2001. Effect of waterlogging on the growth and nutrient metabolism of the root system of winter wheat. Acta Agron. Sin. 27(5):673-679. 
1017

1018

1019

1020

1021

1022

1023

1024

1025

1026

1027

1028

1029

1030

1031

1032

1033

1034

1035

1036

1037

1038

1039

1040

1041

1042

1043

1044

1045

1046

\section{Legends of the figures:}

Fig. 1. A modified conceptual model of the nitrogen biogeochemical cycle between atmosphere and terrestrial ecosystem - input, output, process, dynamics, and management. Atmospheric nitrogen $(\mathrm{N})$ is transformed by lighting process (1), biological $\mathrm{N}_{2}$ fixation (2), $\mathrm{N}$ deposition (3), Haber-Bosch process (4), and through application $\mathrm{N}$ fertilizer (5), finally imported into terrestrial and aquatic ecosystems; in plants, $\mathrm{N}$ converts from $\mathrm{NO}_{3}{ }^{-1}$ into $\mathrm{NH}_{4}{ }^{+}$by nitrate reductase (6) and nitrite reductase (7) involvements, and continual conversions between crops, animal and people (8). In soil, $\mathrm{N}$ in organic matter is first mineralized to inorganic $\mathrm{N}$ forms such as $\mathrm{NH}_{4}{ }^{+}$and $\mathrm{NO}_{3}{ }^{-}$(9-11), in which nitrification occurs with microbial involvements; some $\mathrm{N}$ components can be fixed in soil as a immobilized form(13). Thereafter, available inorganic $\mathrm{N}$ is absorbed by plant roots, again entering plant tissues (12). $\mathrm{N}$ emission paths mainly include denitrification in soil (13), Anammox reaction (14, Meng 2012), gaseous N emission processes (15), and fossil fuel consumption (16). $\mathrm{N}$ fluxes between atmosphere and terrestrial ecosystem are indicated by the red (output) and green (input) data (Tg N a ${ }^{-1)}$ (Lam et al. 1996; Vitousek et al. 1997; Aber et al. 1998; Galloway et al. 2008; Fowler et al. 2013; Chen et al. 2014b).

Fig. 2. A schematic representation of the major responses of nitrogen $(\mathrm{N})$ bioprocesses in terrestrial ecosystems due to climate change (a, elevated $\mathrm{CO}_{2} ; \mathbf{b}$, drought with heat). Notes: (a) elevated $\mathrm{CO}_{2}$ concentrations affect plant biological processes (1), including decreased leaf $\mathrm{N}$ content (2), increased use efficiency (NUE) and photosynthetic N use efficiency (PNUE) (3), progressive N limitations to plants (PNL), and an decrease in net primary productivity (NPP) (e.g., Davey et al. 1999; Luo et al. 2004; Xu et al. 2007; Bloom et al. 2012; Gutiérrez et al. 2013). In soils under high $\mathrm{CO}_{2}$ concentrations, the available $\mathrm{N}$ content decreases (4) while the soil organic matter (SOM) content increases (5), which results in more ammonia production (6, Groenigen 2014; Rütting and Andresen 2015). Furthermore, elevated $\mathrm{CO}_{2}$ would enhance plant root systems (e.g., Xu et al. 2007) and potentially accelerate soil mineralization (7). However, the effects on soil microbiota and soil fauna depend on ecosystems and species (O'Neill 1995; Hu et al. 2001; $\mathrm{Xu}$ et al. 2013a), which result in complicated effects on $\mathrm{N}$ process underground (8, 9; Rütting and Andresen 2015; Vestergård et al. 2015). (b) A combination of drought and heat can affect plant biological processes (1), weaken $\mathrm{N}$ anabolism and promote $\mathrm{N}$ catabolism (2, 3: e.g., $\mathrm{Xu}$ and Zhou 2006a), limiting plant growth and NPP. In the soil, the two combined stresses may decrease, remain constant, or increase the soil available $\mathrm{N}$ level (4, Xu and Yu 2005; Xu et al. 2007; Yuan et al. 2006; Gestel et al. 2011; Rustad et al. 2001), depending 
1047

1048

1049

1050

1051

1052

1053

1054

1055

1056

1057

on the severity of heating (Gestel et al. 2011; Rustad et al. 2001). However, drought may result in lower SOM contents (5) and gross $\mathrm{N}$ turnover rates (including the ammonification process) (6, Chen et al. 2011b; Larsen et al. 2011), potentially due to limited root growth due to drought (7, Xu et al. 2007). Finally, microbiota activity, including the $\mathrm{N}_{2}$ fixation bioprocess, may be inhibited by drought ( 8 , Vadez et al. 2000; Coleto et al. 2014). The activity of soil fauna may be constrained by negative climatic change factors, such as drought and heat, subsequently, the soil $\mathrm{N}$ process was negatively affected (9, Vestergård et al. 2015). Elevated $\mathrm{CO}_{2}$, drought and heat may interact $(10,11)$. For example, drought with heat can limit the enhancement of plant biological processes due to $\mathrm{CO}_{2}$ enrichment (Larsen et al. 2011; Penuelas et al. 2013; $\mathrm{Xu}$ et al. 2014). The soil microbial biomass $\mathrm{N}$ pool and litter $\mathrm{C}: \mathrm{N}$ ratio could increase under elevated $\mathrm{CO}_{2}$ but decrease when subjected to heat and drought (Vestergård et al. 2015), whereas N:P has opposite responses to elevated $\mathrm{CO}_{2}$, heat and drought (11, Yuan and Chen 2015). 
Figure 1

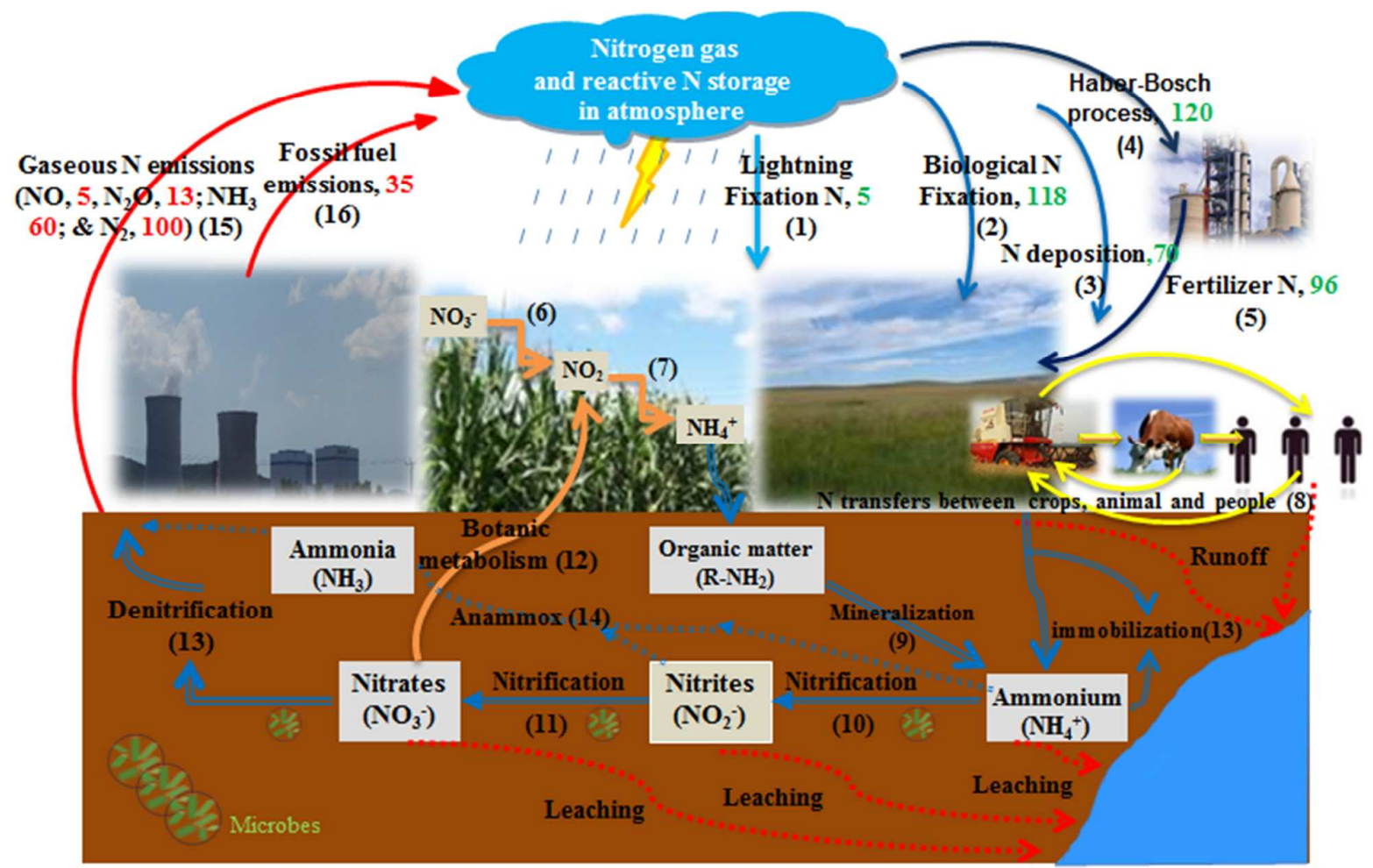


Figure 2

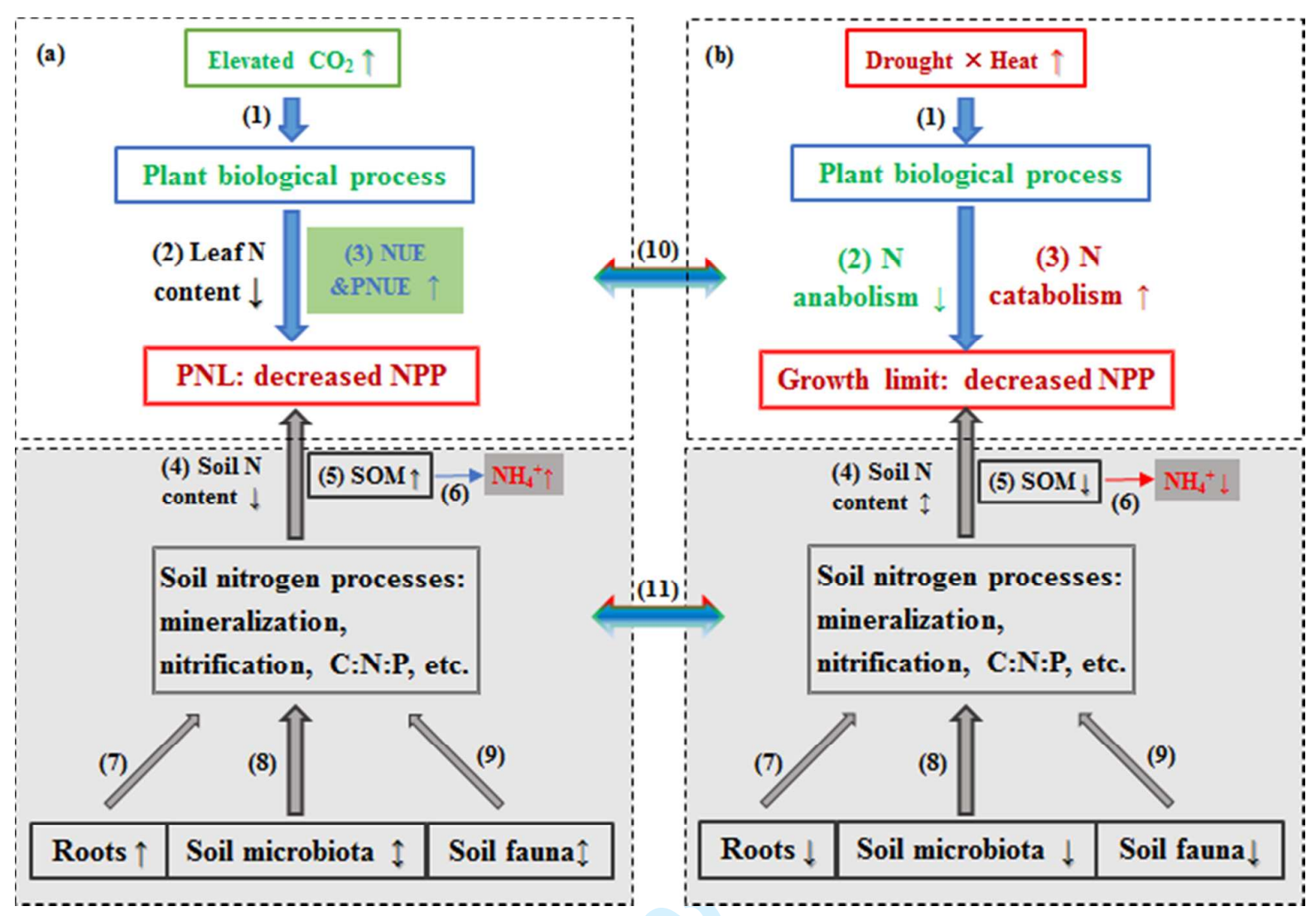

